\title{
Heme Oxygenase-1 Restores Impaired GARP+CD4+CD25+ Regulatory T Cells from Patients with Acute Coronary Syndrome by Upregulating LAP and GARP Expression on Activated T Lymphocytes
}

\author{
Yuzhou Liu ${ }^{a}$ Xiaoqi Zhao Yucheng Zhonga Kai Meng $^{\mathrm{b}}$ Kunwu Yu ${ }^{\mathrm{a}}$ \\ Huairui Shia Bangwei Wu ${ }^{a}$ Hasahya Tony ${ }^{a}$ Jianghao Zhu ${ }^{a}$ Ruirui Zhu ${ }^{a}$ \\ Yudong Penga Yi Mao ${ }^{a}$ Peng Chenga Xiaobo Mao ${ }^{a}$ Qiutang Zenga \\ aThe Laboratory of Cardiovascular Immunology, Institute of Cardiology, Union Hospital, Tongji Medical \\ College, Huazhong University of Science and Technology, Wuhan, China; ${ }^{b}$ Department of Cardiology, \\ the Second Hospital of Shandong University, Jinan, China
}

\section{Key Words}

Heme oxygenase- $1 \cdot \mathrm{GARP}^{+} \mathrm{CD} 4^{+} \mathrm{CD} 25^{+}$Tregs $・ \mathrm{LAP} \cdot$ Foxp3 $\bullet$ Acute coronary syndrome

\begin{abstract}
Background: Accumulating evidence shows that the pathological autoreactive immune response is responsible for plaque rupture and the subsequent onset of acute coronary syndrome (ACS). Naturally occurring CD4+CD25+regulatory T cells (nTregs) are indispensable in suppressing the pathological autoreactive immune response and maintaining immune homeostasis. However, the number and the suppressive function of glycoprotein-A repetitions predominant $(\mathrm{GARP}){ }^{+} \mathrm{CD} 4{ }^{+} \mathrm{CD} 25^{+}$activated $\mathrm{n}$ Tregs were impaired in patients with ACS. Recent evidence suggests that heme oxygenase-1 (HO-1) can regulate the adaptive immune response by promoting the expression of Foxp3. We therefore hypothesized that HO-1 may enhance the function of $\mathrm{GARP}^{+} \mathrm{CD} 4^{+} \mathrm{CD} 25^{+}$Tregs in patients with ACS and thus regulate immune imbalance. Methods: T lymphocytes were isolated from healthy volunteers (control, $n=30$ ) and patients with stable angina $(S A, n=40)$ or ACS $(n=51)$. Half of these cells were treated with an $\mathrm{HO}-1$ inducer (hemin) for $48 \mathrm{~h}$, and the other half were incubated with complete RPMI1640 medium. The frequencies of T-helper 1 (Th1), Th2, Th17 and latency-associated peptide $(\mathrm{LAP}){ }^{+} \mathrm{CD} 4{ }^{+} \mathrm{T}$ cells and the expression of Foxp3 and GARP by $\mathrm{CD} 4{ }^{+} \mathrm{CD} 25^{+} \mathrm{T}$ cells were then assessed by measuring flow cytometry after stimulation in vitro. The suppressive function of activated Tregs was measured by thymidine uptake. The levels of transforming growth factor-1 (TGF- $\beta 1$ ) in the plasma were measured using enzyme-linked immunosorbent assay

Y. Liu, X. Zhao and Y. Zhong contributed equally to this work.

Qiutang Zeng

Laboratory of Cardiovascular Immunology, Institute of Cardiology, Union Hospital Tongji Medical College, Huazhong University of Science and Technology, 1277 Jie-Fang Avenue, Wuhan 430022 (China)

Tel. +86-27-85726423, Fax +86-27-85726014, E-Mail zengqt139@sina.com
\end{abstract}

KARGER 125 


\section{Cellular Physiology and Biochemistry}

Cell Physiol Biochem 2015;35:553-570

\begin{tabular}{l|l}
\hline DOI: $10.1159 / 000369719$ & (C) 2015 S. Karger AG, Basel
\end{tabular}

www.karger.com/cpb

Liu et al.: HO-1 Restores GARP+Tregs from Patients with ACS

(ELISA). The expression levels of the genes encoding these proteins were analyzed by realtime polymerase chain reaction. Results: Patients with ACS exhibited an impaired number and suppressive function of $\mathrm{GARP}^{+} \mathrm{CD}^{+} \mathrm{CD}_{2} 5^{+}$Tregs and a mixed Th1/Th17-dominant T cell response when compared with the SA and control groups. The expression of LAP in T cells was also lower in patients with ACS compared to patients with SA and the control individuals. Treatment with an $\mathrm{HO}-1$ inducer enhanced the biological activity of $\mathrm{GARP}^{+} \mathrm{CD} 4^{+} \mathrm{CD} 25^{+}$Tregs and resulted in increased expression of LAP and GARP by activated T cells. Conclusions: The reduced number and impaired suppressive function of GARP+ $C D 4^{+} \mathrm{CD} 25^{+}$Tregs result in excess effector T cell proliferation, leading to plaque instability and the onset of ACS. HO-1 can effectively restore impaired GARP+ $C D 4^{+} \mathrm{CD} 25^{+}$Tregs from patients with ACS by promoting LAP and GARP expression on activated T cells.

Copyright (C) 2015 S. Karger AG, Basel

\section{Introduction}

Although atherosclerosis (AS) is a complicated pathophysiological process that involves multifactorial disorders, an increasing number of studies have demonstrated that AS is a chronic immunoinflammatory $[1,2]$. AS is the pathological basis of acute coronary syndrome (ACS), which is defined as the erosion or rupture of coronary atherosclerotic plaques with subsequent platelet aggregation and formation of an intracoronary thrombus [3].

One of the key causes of coronary atherosclerotic plaque destabilization is that a considerable number of activated $\mathrm{T}$ cells are recruited in peripheral circulation and atherosclerotic plaques of patients with ACS $[4,5]$, and these T cells exert proatherogenic and plaque-destabilizing effects $[6,7]$. Numerous investigations have reported remarkably increased T helper-1(Th1) cells in the plaques and peripheral blood of patients with ACS [8-10]. This predominance of Th1 cells elicits a strong immunoinflammatory cascade via the secretion of interferon- $\gamma($ IFN- $\gamma$ ) and tumor necrosis factor- $\alpha$ (TNF- $\alpha$ ) that leads to plaque instability and rupture [11]. In addition, Th17 was shown to play a role in the promotion of plaque instability of ACS by producing Interleukin 17 (IL-17), IL-6, TNF- $\alpha$, macrophage chemoattractant protein-1 (MCP-1), macrophage inflammatory chemokine-2 (MIP-2) and matrix metalloproteases $[12,13]$. Therefore, the mixed Th1/Th17-dominant T cell response is largely responsible for the development of ACS because of the pivotal role of these cells in the progress of AS and in plaque destabilization.

Regulatory $\mathrm{T}$ cells (Tregs) are activated by antigens and then efficiently maintain peripheral immune homeostasis by inhibiting the hyperproliferation of Th1 and Th17 cells. However, clinical data have indicated that the frequency of activated nTregs is decreased and their functional properties are compromised in patients with ACS $[14,15]$. The forkhead/ winged helix (Foxp3) transcription factor is a master transcriptional regulator of nTregs cells and is thought to control both the development and function of this $\mathrm{T}$ cell subset [16]. In both humans and mice, defective Foxp3 signaling causes nTreg insufficiency and dysfunction leading to the hyperactivation of effector $\mathrm{T}$ cells and fatal autoimmune diseases $[17,18]$. Therefore, Foxp 3 was previously considered to be a specific biological molecular marker for activated nTregs. However, further studies showed that Foxp3 expression is also found in activated effector T cells (Tresp) in humans [19]. Thus, the use of Foxp3 as specific biomarker for activated human nTregs has been questioned. Recent studies have shown that glycoprotein A repetitions predominant (GARP) is specifically expressed on activated human nTregs and is not induced on non-nTregs after T cell receptor (TCR) [20]. Moreover, GARP ${ }^{+}$ $\mathrm{CD} 4^{+} \mathrm{CD} 25^{\text {hi }}$ Foxp $3^{+}$Tregs showed greater suppressive function than GARP-CD4 ${ }^{+}$CD2 $5^{\text {hi }}$ Foxp3 ${ }^{+}$Tregs [21]. Thus, GARP ${ }^{+} \mathrm{CD} 4^{+} \mathrm{CD} 25^{+}$Tregs may be more suitable for distinguishing bona fide activated human nTregs with high suppressive capacity from Tresp and induced Tregs. TGF- $\beta$ is a pleiotropic cytokine and can be secreted or expressed on the membrane of many cell types in a small latent form along with the latency-associated peptide (LAP) that non-covalently associates with mature TGF- $\beta$ to inhibit its activity. Latent TGF- $\beta$ must cleave the LAP to acquire biological activity. Sockis et al. confirmed that the membrane protein 


\section{Cellular Physiology and Biochemistry}

Cell Physiol Biochem 2015;35:553-570

DOI: $10.1159 / 000369719$

Publisned onine: January 27, 2015

(c) 2015 S. Karger AG, Basel

www.karger.com/cpb

GARP serves as a receptor for latent TGF- $\beta$ on the surface of activated human Tregs, where releases active TGF- $\beta$ by directly binding to the LAP of latent TGF- $\beta$ [22].

Heme oxygenase $(\mathrm{HO})$ is a rate-limiting enzyme in heme degradation that releases biliverdin, carbon monoxide, and free iron by catalyzing heme. The HO family consists of the three isoforms HO-1, HO-2, and HO-3. Among these isoforms, HO-1 is the most important heme-degrading enzyme and is induced by its own substrate, oxidative stress and in response to inflammatory cytokines [23]. Although many studies have indicated that HO-1 may play a role in adaptive immunity, the mechanism of HO-1 in this process remained controversial [24-26]. Recent research further demonstrated that HO-1 is involved in the regulation of adaptive immunity by up-regulating the expression of Foxp 3 on $C D 4^{+} \mathrm{CD} 25^{+}$Tregs in animal models [27]. However, no studies have examined whether HO-1 could enhance the number and the suppressor function of GARP ${ }^{+} \mathrm{CD} 4^{+} \mathrm{CD} 25^{+}$Tregs in patients with ACS. Thus, the current study sought to investigate the effect of HO-1 on the levels and immunosuppressive function of GARP ${ }^{+} \mathrm{CD} 4^{+} \mathrm{CD} 25^{+}$Tregs in different groups of patients and explore the potential mechanisms by which $\mathrm{HO}-1$ regulates adaptive immunity.

\section{Materials and Methods}

\section{Patients}

After rigorous screening, a total of 121 patients from Wuhan Union Hospital were recruited to the study during the period from November 2012 to March 2014. The study included the following three patient groups: (1) Healthy volunteers (control; 21 men and 9 women, mean age $53 \pm 6$ years) with no angina and coronary risk factors were recruited. All of these healthy volunteers had normal electrocardiography and no evidence of atherosclerosis by coronary angiography; (2) Patients with stable angina (SA ; 28 men and 12 women, mean age $57 \pm 5$ years), including those with typical effort angina lasting more than 3 months without changes in angina frequency or severity and coronary angiography showing coronary artery stenosis $\geq 75 \%$; and (3) Patients with acute coronary syndrome (ACS) including 30 cases of acute myocardial infarction (AMI) and 21 cases of unstable angina (UA); 35 men and 16 women; mean age $56 \pm 5$ years). Unstable angina was defined as chest pain at rest with transient myocardial ischemia electrocardiographic changes (ST-segment depression and/or T-wave inversions) and the absence of serum biomarkers of myocardial necrosis. Acute myocardial infarction was confirmed by a significant increase in the levels of myocardial necrosis biomarkers (especially creatine kinase MB and troponin I), as well as severe, persistent, and typically substernal pain.

The following patients were excluded from our study: (1) those with a history of taking statins or anti-inflammatory drugs; (2) those with rheumatic heart disease, or valvular heart disease; (3) those with inflammatory disease, malignant disease, advanced liver disease, or renal failure; (4) those with thromboembolism, disseminated intravascular coagulation, or connective tissue disease; and (5) those with atrial fibrillation or a pacemaker.

All of the patients signed informed consent forms. Our research strictly conformed to the principles of the Declaration of Helsinki and was approved by the ethics committee of Tongji Medical College of Huazhong University of Science and Technology.

\section{Blood samples}

Blood samples were collected from all patients upon admission and within $24 \mathrm{~h}$ of the onset of symptoms. After centrifugation, peripheral blood mononuclear cells (PBMCs) were prepared by Ficoll density gradient separation for the isolation of $\mathrm{T}$ lymphocytes. The plasma was aliquoted and stored at $-80^{\circ} \mathrm{C}$ until further use.

\section{Isolation of T cells and TCR stimulation}

After washing twice in RPMI-1640 medium (Gibco), PBMCs were resuspended at a density of $3 \times 107$ cells/ml in complete culture medium (RPMI-1640 medium supplemented with $100 \mathrm{U} / \mathrm{ml}$ penicillin, 100 $\mu \mathrm{g} / \mathrm{ml}$ streptomycin, $2 \mathrm{mM}$ glutamine and $10 \%$ heat-inactivated fetal calf serum, Gibco). Cells were cultured in a volume of $1 \mathrm{ml}$ at $37^{\circ} \mathrm{C}$ in $5 \% \mathrm{CO}_{2}$ in a nylon wool column for $2 \mathrm{~h}$, and $6 \mathrm{ml}$ of prewarmed medium was 


\section{Cellular Physiology and Biochemistry}

Cell Physiol Biochem 2015;35:553-570

DOI: $10.1159 / 000369719$

Published online: January 27, 2015

C) 2015 S. Karger AG, Basel

www.karger.com/cpb

passed through the column to obtain T cells. Flow cytometry was performed to detect the purity of the isolated $\mathrm{T}$ cells. The $\mathrm{T}$ cells were equally divided and half were incubated in complete culture medium for 48h and then stimulated with soluble anti-human CD3 (3 $\mu \mathrm{g} / \mathrm{ml}$, eBioscience) and anti-human CD28 (1 $\mu \mathrm{g} /$ $\mathrm{ml}$, eBioscience) antibodies in a 24 -well plate $\left(1 \times 106 /\right.$ well) for $24 \mathrm{~h}$ at $37^{\circ} \mathrm{C}$ under $5 \% \mathrm{CO}$. The remaining $\mathrm{T}$ cells were incubated with $10 \mathrm{ng} / \mathrm{ml}$ hemin in a 24 -well plate $(1 \times 106 /$ well $)$ for $48 \mathrm{~h}$ and then stimulated with anti-human CD3 (3 $\mu \mathrm{g} / \mathrm{ml}$, eBioscience) and anti-human CD28 (1 $\mu \mathrm{g} / \mathrm{ml}$, eBioscience $)$ antibodies for $24 \mathrm{~h}$ at $37^{\circ} \mathrm{C}$ under $5 \% \mathrm{CO}_{2}$.

Flow cytometric analysis

After $24 \mathrm{~h}$ of culture, the isolated T cells were harvested and placed in sterile tubes. The cells were then centrifuged at $420 \times \mathrm{g}$ for $6 \mathrm{~min}$ and aliquoted into two tubes to stain for Tregs and Th cells.

For Tregs analysis, cell surface staining was performed using anti-human CD4-FITC (eBioscience), anti-human CD25-APC (eBioscience), anti-human GARP-PE (eBioscience), and anti-human LAP-PECy7 (eBioscience) antibodies at $4^{\circ} \mathrm{C}$ for $30 \mathrm{~min}$. After surface staining, the cells were washed in phosphatebuffered saline (PBS), fixed and permeabilized with fix/permeabilization reagent at $4^{\circ} \mathrm{C}$ for $30 \mathrm{~min}$, washed twice in $1 \times$ permeabilization-buffer and incubated with an anti-human Foxp3-PECy5 (eBioscience) antibody at $4^{\circ} \mathrm{C}$ for $30 \mathrm{~min}$.

For Th cell analysis, T cells were seeded at a density of $1 \times 106$ cells/well in RPMI-1640 medium with $10 \%$ heat-inactivated fetal calf serum (Gibco) and stimulated with phorbol myristate acetate (PMA, $50 \mathrm{ng} /$ $\mathrm{ml}$, Sigma), ionomycin ( $1 \mu \mathrm{M}$, Sigma) and monensin ( $500 \mathrm{ng} / \mathrm{ml}$, eBioscience) for $4 \mathrm{~h}$ at $37^{\circ} \mathrm{C}$ under $5 \% \mathrm{CO} 2$. The cells were then incubated with anti-human CD4-FITC (eBioscience)antibody at $4^{\circ} \mathrm{C}$ for $30 \mathrm{~min}$, washed twice in $1 \times$ permeabilization-buffer and stained with anti-human IFN- $\gamma$ - PE, anti-human IL-17-PE or antihuman IL-4-PE (eBioscience) antibody at $4^{\circ} \mathrm{C}$ for $30 \mathrm{~min}$.

All of the cells were analyzed using a FACScan cytometer equipped with CellQuest software (BD Bioscience Pharmingen).

\section{Proliferation and functional suppression assays}

After $24 \mathrm{~h}$ of stimulation with soluble anti-human CD3 and anti-human CD28 antibodies, PBMCs from control $(n=10), S A(n=10)$ and ACS $(n=11)$ patients were purified using a CD4+T cell positive isolation kit (Miltenyi Biotec, Bergisch Gladbach Germany) and FACS sorting using a FACS Aria (BD Biosciences) to obtained purified GARP+CD4+CD25+Tregs and GARP-CD4+CD25-Tresps. The purities of the GARP+CD4+ CD25+regulatory T cells and GARP-CD4+CD25-Tresps were determined by flow cytometry and were greater than $95 \%$.

The following groups were used to measure the proliferation or suppression of Tresps and Tregs: (1) GARP-CD4+CD25-Tresps cultured alone (104/well); (2) GARP+CD4+CD25+Tregs cultured alone (104/ well); and (3) Tregs and Tresps co- cultured at different Tregs/Tresps ratios (1:1,1:2, 1:4 and 1:8). All of the cells were cultured in complete RPMI-1640 in a final volume of $200 \mu \mathrm{l}$ in the presence of $105 \mathrm{~T}$ cell-depleted and irradiated antigen-presenting cells per well. The cells were incubated with plate-bound anti-human CD3 $(5 \mu \mathrm{g} / \mathrm{ml}$, eBioscience $)$ and soluble anti-human CD28 (2 $\mu \mathrm{g} / \mathrm{ml}$, eBioscience) antibodies at $37^{\circ} \mathrm{C}$ in $5 \%$ $\mathrm{CO}_{2}$ for $72 \mathrm{~h}$ in 96 -well plates. Next, $1 \mu \mathrm{l}$ of [3H]-thymidine (eBiosciences) was added to each well for the final $16 \mathrm{~h}$ of culture, and proliferation was assessed using a scintillation counter (PerkinElmer). Suppression was expressed as a percentage of the positive control.

\section{Quantitative real-time polymerase chain reaction (RT-PCR)}

According to the manufacturer's instructions, total RNA was extracted with RNAiso Plus (Takara), and cDNA was synthesized using a RNA PCR Kit (Takara). Target genes were analyzed using SYBR Green Master Mix (Takara) with an ABI Prism 7900 Sequence Detection System (Applied Biosystems). Each sample was analyzed at least in duplicate. The primer sequences used are listed in Table 1.

The relative mRNA levels were calculated using the comparative CT formula $2^{-\Delta \Delta C T}$ and normalized to the expression of the housekeeping gene GAPDH.

Treatment of T Cells with hemin

Freshly isolated $\mathrm{T}$ cells were treated with hemin at various concentrations for different time periods, and the expression of HO-1 mRNA was measured by RT-PCR. Half of the T cells isolated from each patient 


\section{Cellular Physiology and Biochemistry}

Cell Physiol Biochem 2015;35:553-570

DOI: $10.1159 / 000369719$

C 2015 S. Karger AG, Base

Liu et al.: HO-1 Restores GARP+Tregs from Patients with ACS

were incubated with $10 \mathrm{ng} / \mathrm{ml}$ hemin in a 24 -well plate $\left(1 \times 10^{6} /\right.$ well $)$ for $48 \mathrm{~h}$ and then stimulated with soluble anti-human CD3 (3 $\mathrm{g} / \mathrm{ml})$ and anti-human CD28 (1 $\mu \mathrm{g} / \mathrm{ml})$ antibodies for $24 \mathrm{~h}$ at $37^{\circ} \mathrm{C}$ under $5 \%$ $\mathrm{CO}_{2}$. After stimulation, the frequency of Th1, Th2, and Th17 cells and GARP ${ }^{+} \mathrm{CD} 4{ }^{+} \mathrm{CD} 25^{+}$Tregs, the function of $\mathrm{GARP}^{+} \mathrm{CD} 4^{+} \mathrm{CD} 25^{+}$Tregs and the related gene expression were re-evaluated.

Cytokine detection of plasma TGF- $\beta$

The levels of TGF- $\beta 1$ in the plasma were measured using an enzyme-linked immunosorbent assay (ELISA) kit (eBioscience). All samples were assayed at least in triplicate.

\section{Statistical analysis}

Values were expressed as the mean \pm standard deviation (SD). Significant differences between the three groups were determined using a one-way analysis of variance (ANOVA) with the Newman-Keuls posttest and the Dunnett adjustment test. Differences in T cells before and after treatment with HO- 1 were compared by the Wilcoxon signed-rank test. Spearman's correlation was performed as a test of correlation between two continuous variables. P values $<0.05$ were considered statistically significant.

Table 1. RT- PCR primer sequences

\section{Results}

Basic clinical characteristics

The baseline characteristics of the control, SA and ACS groups are listed in Table 2. There were no significant differences in age, gender, risk factors, or medications between the groups.

The frequency of $G A R P+C D 4+C D 25+$ Tregs is reduced in activated $T$ cells from patients with ACS

The $\mathrm{T}$ cells from all the subjects were analyzed after activation with anti-CD3 and anti-CD28 antibodies. The frequencies of $\mathrm{CD}^{+} \mathrm{CD} 25^{+} \mathrm{T}$ cells were detected by flow cytometry (Fig. 1A), and no significant differences were detected among the three groups $(\mathrm{P}=0.36)$. However, after measuring the expression of GARP in $\mathrm{CD}^{+} \mathrm{CD} 25^{+} \mathrm{T}$

\begin{tabular}{|c|c|c|c|}
\hline \multirow{8}{*}{$\begin{array}{l}\text { istics } \\
\text { teristics of the } \\
\text { are listed in Table } \\
\text { nt differences in } \\
\text { or medications }\end{array}$} & Gene & \multicolumn{2}{|c|}{ Sequence(5'-3') } \\
\hline & Foxp3 sense & \multicolumn{2}{|c|}{ CACTTGCAGACACCATTTGC } \\
\hline & Foxp3 antisense & \multicolumn{2}{|c|}{ CTCTTCTTCCTTGAACCCCA } \\
\hline & T-bet sense & \multicolumn{2}{|c|}{ GATGTTTGTGGACGTGGTCTTC } \\
\hline & T-bet antisense & \multicolumn{2}{|c|}{ CTTTCCACACTGCACCCACTT } \\
\hline & IFN- $\gamma$ sense & \multicolumn{2}{|c|}{ GGTTCTCTTGGCTGTTACTGCC } \\
\hline & IFN $-\gamma$ antisense & \multicolumn{2}{|c|}{ TTGGACATTCAAGTCAGTTACC } \\
\hline & GATA3 sense & \multicolumn{2}{|c|}{ GGACGCGGCGCAGTA C } \\
\hline & GATA3 antisense & \multicolumn{2}{|c|}{ TGCCTTGACCGTCGATGTTA } \\
\hline & IL-4 sense & \multicolumn{2}{|c|}{ GCCACCATGAGAAGGACACT } \\
\hline$R P+C D 4+C D 25+$ & IL-4 antisense & \multicolumn{2}{|c|}{ ACTCTGGTTGGCTTCCTTCA } \\
\hline ted $T$ cells from & TGF- $\beta 1$ sense & \multicolumn{2}{|c|}{ CAGCAACAATTCCTGGCGATAC } \\
\hline & TGF- $\beta 1$ antisense & \multicolumn{2}{|c|}{ TGGGCGCTAAGGCGAAAG } \\
\hline & ROR $\gamma$ t sense & \multicolumn{2}{|c|}{ GCAATGGAAGTGGTGCTGGTT } \\
\hline ojects n & ROR $\gamma$ t antisense & \multicolumn{2}{|c|}{ AGGATGCTTTGGCGATGAGTC } \\
\hline & IL-17 sense & \multicolumn{2}{|c|}{ ACCAATCCCAAAAGGTCCTC } \\
\hline equencies of & IL-17 antisense & \multicolumn{2}{|c|}{ GGGGACAGAGTTCATGTGGT } \\
\hline etected by flow & HO- 1 sense & \multicolumn{2}{|c|}{ ATGACACCAAGGACCAGAGC } \\
\hline no significant & HO- 1 antisense & \multicolumn{2}{|c|}{ GTGTAAGGACCCATCGGAGA } \\
\hline Imong the three & GARP sense & \multicolumn{2}{|c|}{ CGCTCCCGAGACTCATCTAC } \\
\hline & GARP antisense & \multicolumn{2}{|c|}{ GGTCAGGTGCTCAAGAAAGC } \\
\hline CD25+T & GAPDH sense & \multicolumn{2}{|c|}{ GAGTCAACGGATTTGGTCGT } \\
\hline & GAPDH antisense & \multicolumn{2}{|c|}{ GACAAGCTTCCCGTTCTCAG } \\
\hline haracteristics & $\begin{array}{c}\text { Control } \\
(\mathrm{n}=30)\end{array}$ & $\begin{array}{c}\text { SA } \\
(n=40)\end{array}$ & $\begin{array}{c}\text { ACS } \\
(n=51)\end{array}$ \\
\hline ge(years) & $53 \pm 6$ & $57 \pm 5$ & $56 \pm 5$ \#\# \\
\hline iender(male/Female) & $21 / 9$ & $28 / 12$ & $35 / 16$ \#\# \\
\hline \multicolumn{4}{|l|}{ Risk factors } \\
\hline Hypertension, $n(\%)$ & - & $25(63)$ & $35(69) \#$ \\
\hline Diabetes mellitus, $n(\%)$ & - & $9(23)$ & $14(27) \#$ \\
\hline Smoking, $n(\%)$ & - & $21(53)$ & 31(61) \# \\
\hline $\mathrm{TC},(\mathrm{mmol} / \mathrm{L})$ & $4.54 \pm 0.36$ & $4.65 \pm 0.55$ & $4.76 \pm 0.49$ \#\# \\
\hline $\mathrm{TG},(\mathrm{mmol} / \mathrm{L})$ & $1.73 \pm 0.41$ & $2.12 \pm 0.36$ & $2.01 \pm 0.4 \# \#$ \\
\hline $\mathrm{LDL}-\mathrm{C},(\mathrm{mmol} / \mathrm{L})$ & $2.25 \pm 0.31$ & $2.63 \pm 0.27$ & $2.77 \pm 0.25$ \#\# \\
\hline $\mathrm{HDL}-\mathrm{C},(\mathrm{mmol} / \mathrm{L})$ & $1.21 \pm 0.16$ & $1.14 \pm 0.22$ & $1.12 \pm 0.14$ \#\# \\
\hline \multicolumn{4}{|l|}{ Medications } \\
\hline Aspirin (\%) & - & $19(47.5)$ & $27(52.9) \#$ \\
\hline$\beta$-Blockers, n(\%) & - & $13(32.5)$ & $20(39.2) \#$ \\
\hline $\mathrm{CCB}, \mathrm{n}(\%)$ & - & $20(50)$ & $28(54.9) \#$ \\
\hline ACEI/ARB, n (\%) & - & $13(32.5)$ & 18(35.3) \# \\
\hline Nitrates, n (\%) & - & $21(52.5)$ & $30(58.8) \#$ \\
\hline
\end{tabular}

Table 2. Clinical characteristics of the study population. Values are expressed as the mean \pm SD or as a number. SA: Stable angina pectoris; ACS: acute coronary syndromes; TC: total cholesterol; TG: total triglycerides; LDL-C: low-density lipoprotein cholesterol; HDL-C: high-density lipoprotein cholesterol; CCB: calcium channel blocker; ACEI: angiotensin-converting enzyme inhibitor; ARB: angiotensin receptor blocker. \#\#P >0.05 vs. Control or SA; \# P >0.05 vs. SA 

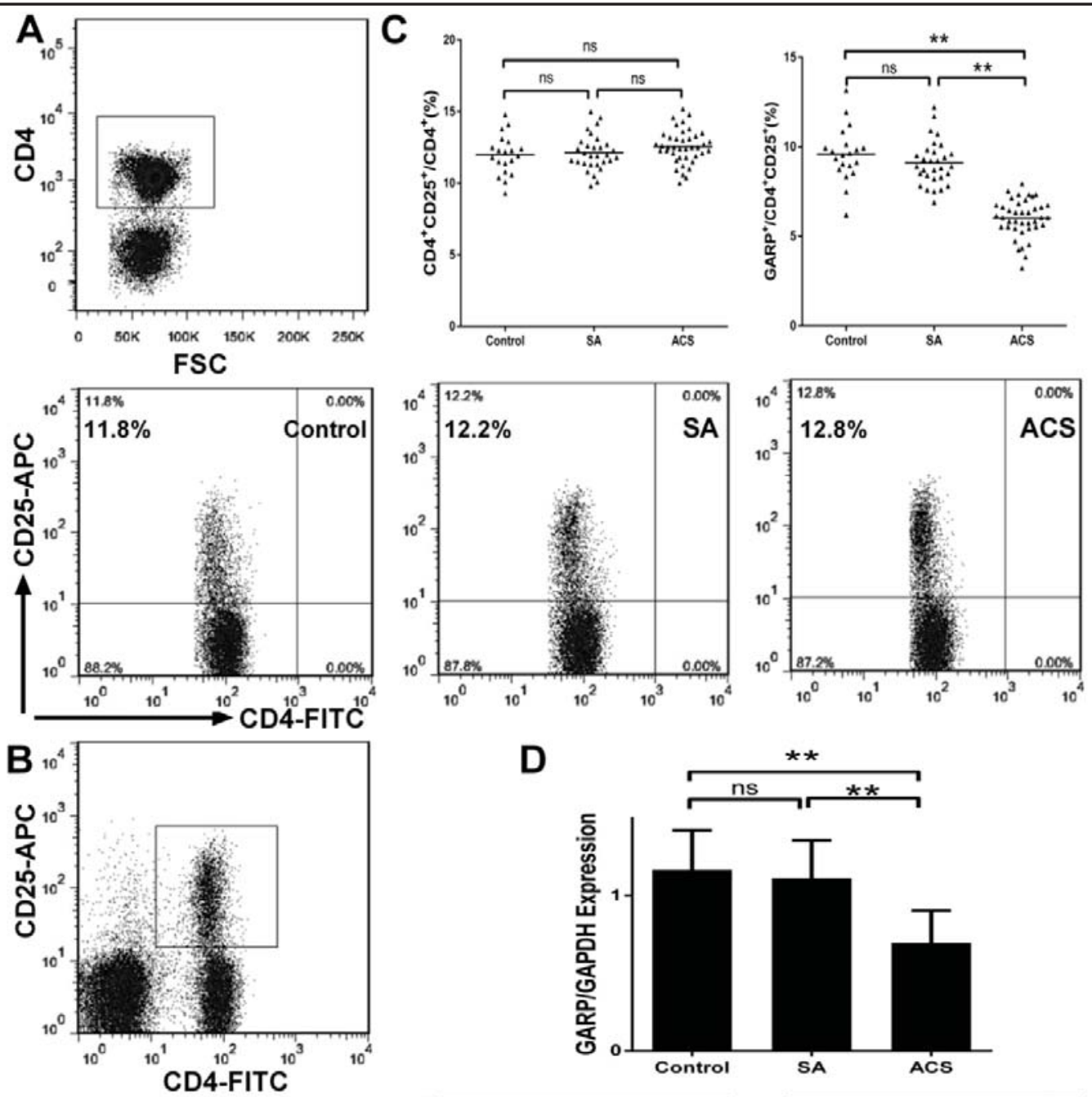

D
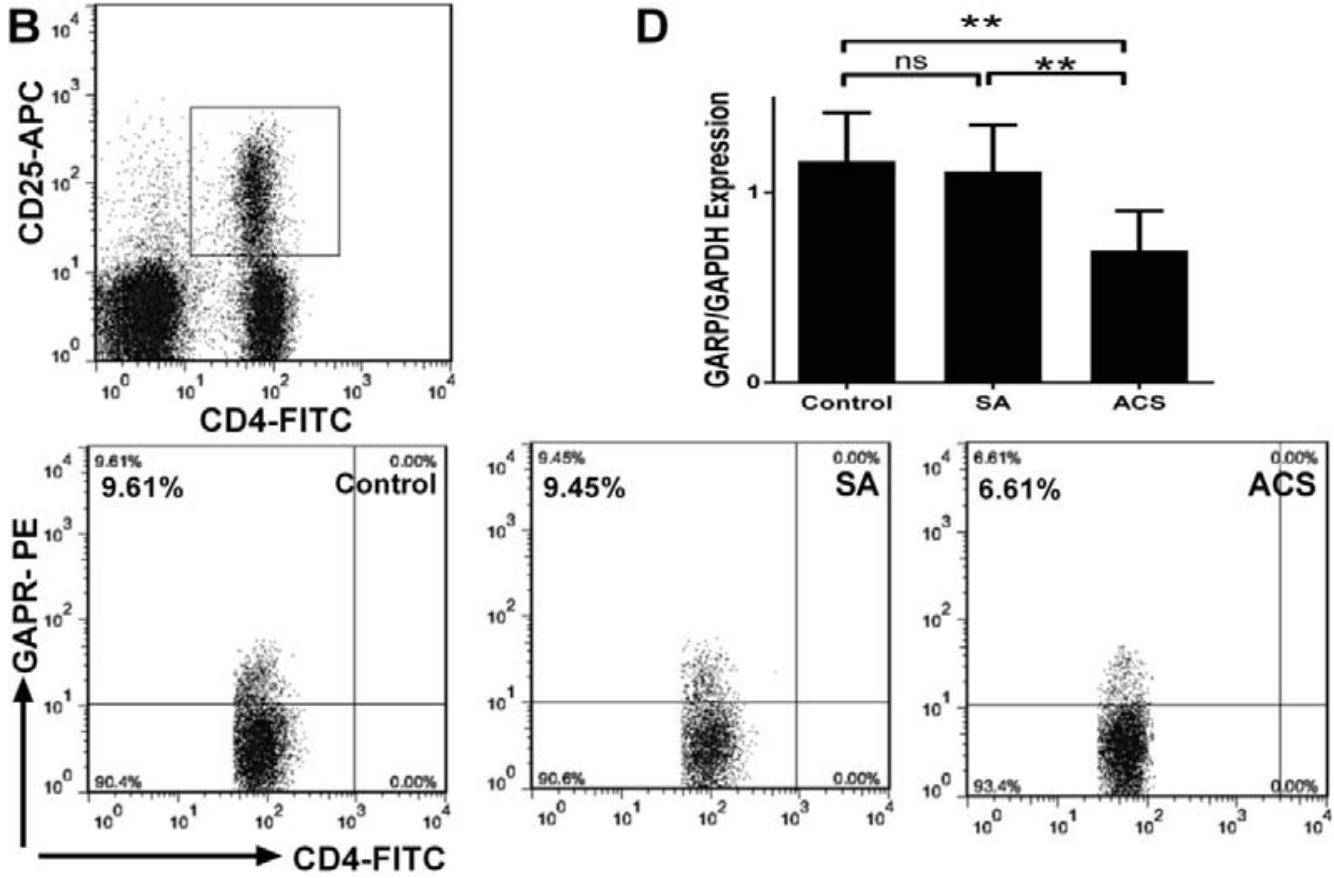

Fig. 1. The expression of GARP was reduced on activated T cells from patients with ACS. Activated T cells were stained with labeled antibodies from control $(n=20)$, SA $(n=30)$ and ACS $(n=40)$ patients. A. Representative FSC/SSC dot plot showing the gated CD4+T cells by the isotype control and representative FACS plots showing the frequencies of $\mathrm{CD} 4{ }^{+} \mathrm{CD} 25^{+} \mathrm{T}$ cells among the stimulated $\mathrm{T}$ cells from each group. $\mathrm{B}$. $\mathrm{CD} 4{ }^{+} \mathrm{CD} 25^{+} \mathrm{T}$ cells were gated by the isotype control, and the representative GARP expression on activated $\mathrm{CD} 4{ }^{+} \mathrm{CD} 25^{+} \mathrm{T}$ cells from one patient in each group is shown. C. The frequencies of $\mathrm{CD} 4^{+} \mathrm{CD} 25^{+} \mathrm{T}$ cells and the expression of GARP on $\mathrm{CD}^{+} \mathrm{CD} 25^{+}$subsets were analyzed in each group. D. Comparison of the mRNA levels of GARP in each group. Error bars, SD; ${ }^{* *} \mathrm{P}<0.01$ vs. control or SA; ns, P >0.05 vs. control.

cells (Fig. 1B), we found that the expression of GARP was sharply reduced in patients with ACS $(6.02 \pm 1.05 \%)$ compared with patients in the SA and control groups $(9.09 \pm 1.23 \%$, 


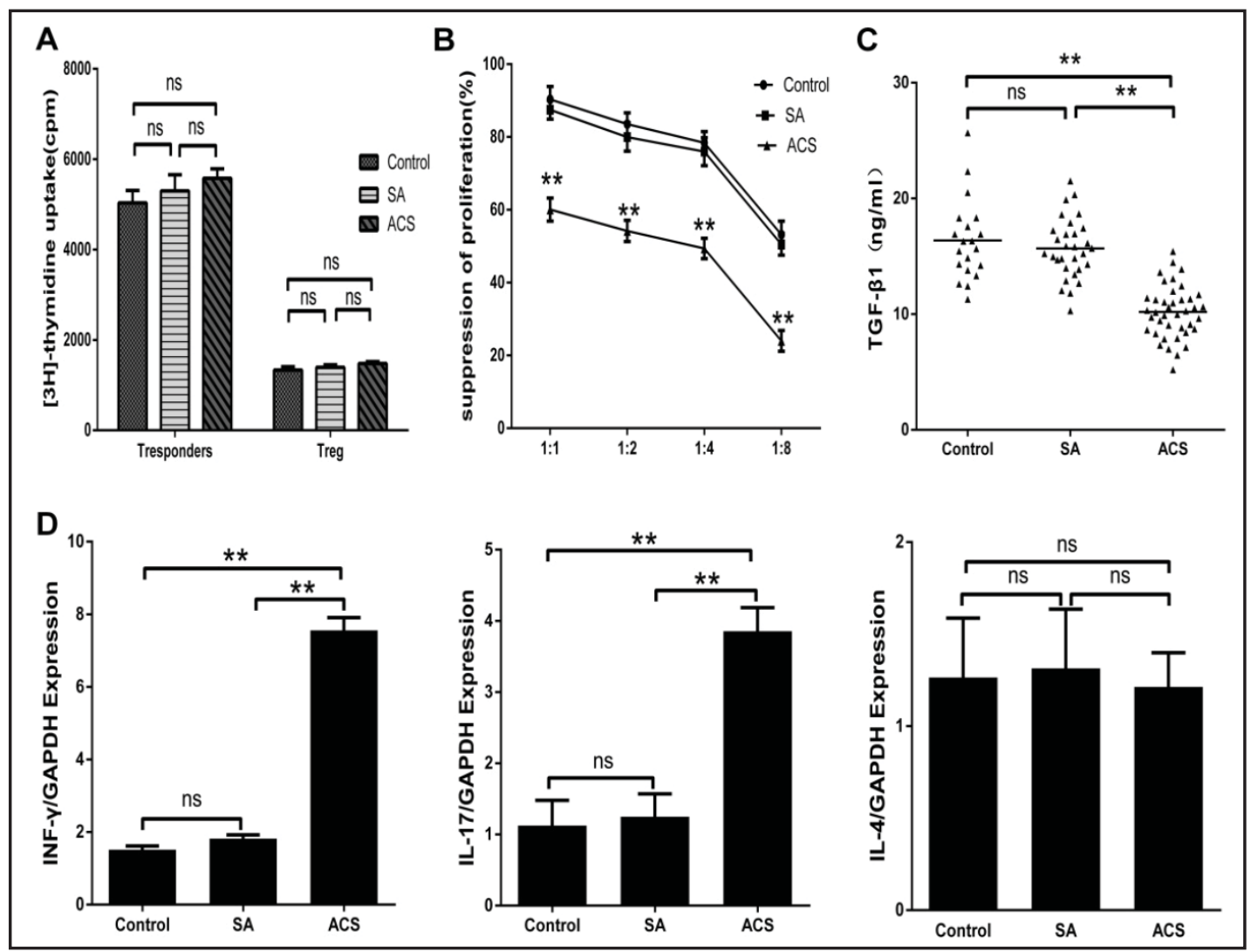

Fig. 2. $\mathrm{GARP}^{+} \mathrm{CD} 4^{+} \mathrm{CD} 25^{+}$Tregs function was compromised in patients with $\mathrm{ACS}$. GARP ${ }^{+} \mathrm{CD} 4^{+} \mathrm{CD} 25^{+} \mathrm{Tregs}$ and GARP-CD $4^{+}$CD25-Tresps were isolated by magnetic bead and FACS sorting from control $(n=10)$, SA $(n=10)$, ACS $(n=11)$ groups. A. The proliferative capacities of $\mathrm{GARP}^{+} \mathrm{CD} 4^{+} \mathrm{CD} 25^{+}$Tregs and Tresps were measured and compared among the three groups. B. The suppressive properties of GARP ${ }^{+} \mathrm{CD} 4^{+} \mathrm{CD} 25^{+}$Tregs from each group were assayed at different ratios and expressed as the mean \pm SD. C. the plasma TGF- $\beta 1$ concentrations were compared between the three groups. D. the IFN- $\gamma$, IL-4 and IL-17 mRNA expression among T cells from ACS, SA and healthy group. Error bars, SD; ${ }^{* *} \mathrm{P}<0.01$ vs. control or SA; ns, $\mathrm{P}>0.05$ vs. control.

9.58 $\pm 1.51 \%$, respectively $\mathrm{P}<0.01$; Fig.1B) after stimulation in vitro, However no significant differences were observed between the $\mathrm{SA}$ and control groups $(\mathrm{P}=0.39$; Fig. 1C).The expression of the GARP gene was consistent with these results ( $\mathrm{P}<0.01$; Fig. 1D).

The function of GARP+CD4+CD25+Tregs is significantly impaired in patients with ACS

$\mathrm{GARP}^{+} \mathrm{CD} 4^{+} \mathrm{CD} 25^{+}$Tregs and GARP-CD4 ${ }^{+} \mathrm{CD} 25-$ Tresps were isolated using magnetic bead and FACS sorting from the control $(n=10)$, SA $(n=10)$, ACS $(n=11)$ groups (purity $>95 \%)$. There were no significant differences in the proliferation of GARP- CD4 ${ }^{+} \mathrm{CD} 25^{-}$Tresps $(\mathrm{P}=0.73)$ or $\mathrm{GARP}{ }^{+} \mathrm{CD} 4^{+} \mathrm{CD} 25^{+}$Tregs $(\mathrm{P}=0.61)$ between the groups (Fig. $\left.2 \mathrm{~A}\right)$.

The suppressor function of GARP ${ }^{+} \mathrm{CD} 4^{+} \mathrm{CD} 25^{+}$Tregs from control $(\mathrm{n}=10), \mathrm{SA}(\mathrm{n}=10)$, ACS $(n=11)$ groups was assessed by co-culturing with autologous Tresps at varying ratios of Tregs to Tresps $(1: 1,1: 2,1: 4$, and 1:8) and expressed as the mean \pm SD. The suppressive properties of Tregs were reduced when increased numbers of Tresps were added to the culture (Fig. 2B). In addition, the suppressor function of Tregs from patients with ACS was significantly impaired in different ratios compared with Tregs isolated from the SA and control group $(\mathrm{P}<0.01$; Fig. 2B).

Because TGF- $\beta$ plays an important role in the suppressive properties of Tregs, plasma TGF- $\beta 1$ concentrations were measured in each group. The TGF- $\beta 1$ concentrations were as follows: $10.2 \pm 2.3 \mathrm{ng} / \mathrm{ml}$ for the ACS group; $15.7 \pm 2.6 \mathrm{ng} / \mathrm{ml}$ for the SA group; and $16.9 \pm 2.9 \mathrm{ng} /$ 
Fig. 3. The level of HO-1 mRNA in freshly isolated $\mathrm{T}$ cells from each group, and the expression of HO-1 mRNA after treatment with hemin at various concentrations and at different times points in vitro. A. The expression of HO-1 mRNA in freshly isolated $T$ cells from the control $(n=10)$, SA $(n=10), \operatorname{ACS}(n=11)$ groups. B. The expression of HO-1mRNA in T cells from 10 patients with ACS treated with various does of hemin. $C$. The expression of HO- 1 mRNA in T cells from 10 patients with ACS treated with $10 \mathrm{ng} / \mathrm{ml}$ hemin at different time points. Error bars, SD; * $\mathrm{P}<0.05$ vs. $48 \mathrm{~h} ;{ }^{* *} \mathrm{P}<0.01$ vs. control or SA; ns, $\mathrm{P}>0.05$ vs. control.

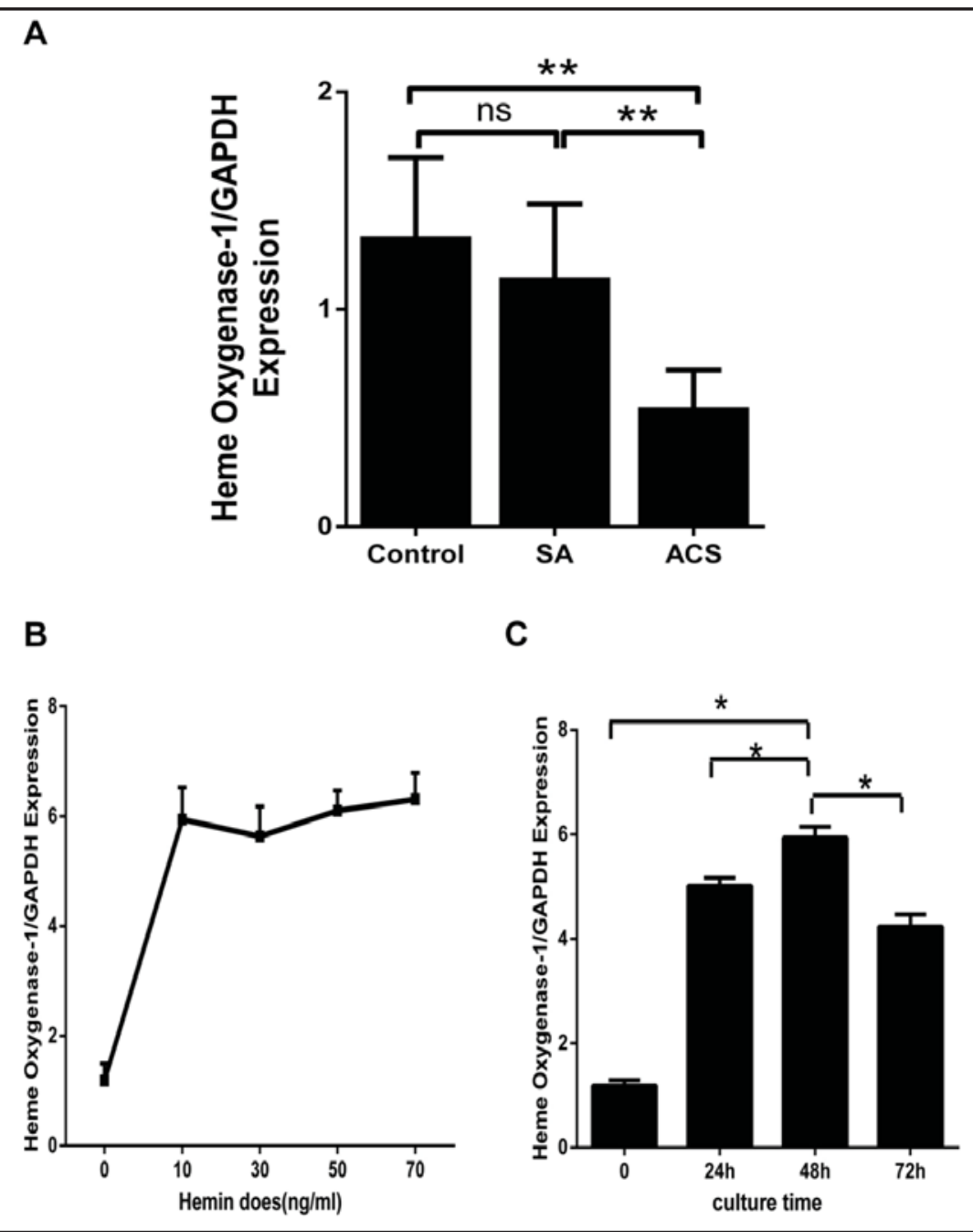

$\mathrm{ml}$ for the control group. The concentrations of TGF- $\beta 1$ in ACS individuals were significantly lower than those in SA or control individuals ( $\mathrm{P}<0.01$; Fig. $2 \mathrm{C}$ ).

Meanwhile, the IFN- $\gamma$, IL-4 and IL-17 mRNA expression levels of stimulated T cells from each group were analyzed. we found that the expression of IFN- $\gamma$ and IL-17 gene expression levels were marked increases in patients with ACS compared with patients in the SA and control groups (all $\mathrm{P}<0.01$; Fig.2D), However no significant differences were observed between the SA and control groups. A similar result was not observed on the IL-4 mRNA expression ( $\mathrm{P}=0.46$; Fig. 2D).

The level of HO-1 mRNA in freshly isolated T cells from each group and the expression of HO-1 mRNA of T cells from the ACS group following treatment with hemin

First, we detected the levels of HO-1 mRNA of freshly isolated T cells from the three groups, and found that the level of HO-1 mRNA was significantly lower in T cells from the ACS group than those from the $\mathrm{SA}$ and control groups $(\mathrm{P}<0.01)$; however, there was no obvious difference between the SA group and control group ( $\mathrm{P}=0.34$; Fig. $3 \mathrm{~A})$. Then, T cells from ACS individuals were treated with hemin, a HO- 1 inducer, at various concentrations $(0,10,30,50$, and $70 \mathrm{ng} / \mathrm{ml})$ for different periods of time $(0,24,48$, and $72 \mathrm{~h})$. As shown in Fig. 3B, 10ng/ $\mathrm{ml}$ hemin was sufficient to markedly induce the expression of HO-1 mRNA. We found that the maximal expression of HO-1 mRNA was induced by treating cells with $10 \mathrm{ng} / \mathrm{ml}$ hemin for $48 \mathrm{~h}(\mathrm{P}<0.05$; Fig. 3C). 


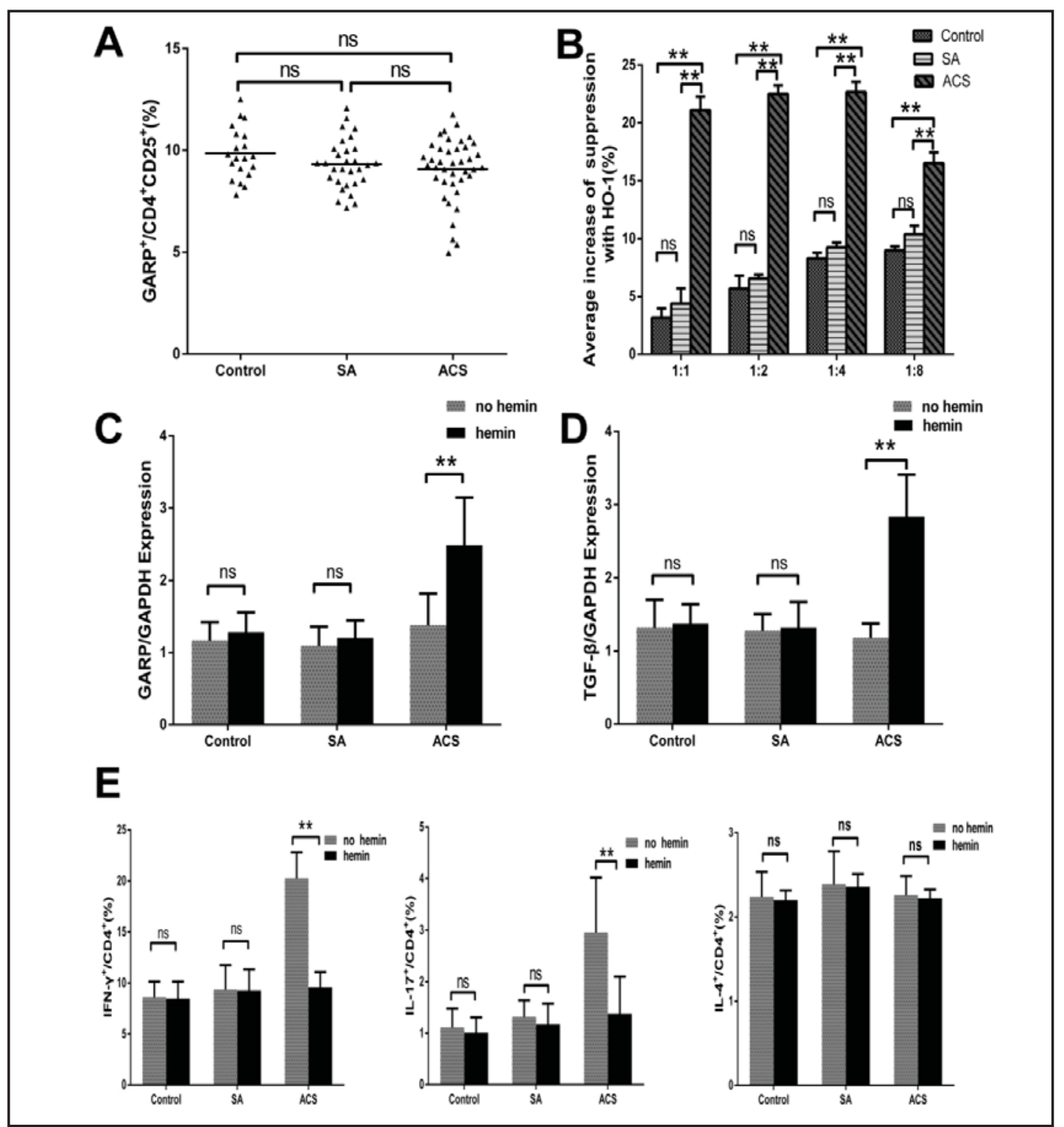

Fig. 4. HO- 1 had a significant effect on $\mathrm{GARP}^{+} \mathrm{CD} 4^{+} \mathrm{CD} 25^{+}$Tregs, $\mathrm{Th} 1$ and Th 17 cells in patients with ACS. T cells from all of the subjects were treated with $10 \mathrm{ng} / \mathrm{ml}$ of hemin for $48 \mathrm{~h} \mathrm{~A}$. GARP expression on $\mathrm{CD} 4{ }^{+} \mathrm{CD} 25^{+} \mathrm{T}$ cells was measured and compared between the three groups after stimulation in vitro. B. An equivalent increase in the suppressor function of GARP ${ }^{+} \mathrm{CD} 4^{+} \mathrm{CD} 25^{+}$Tregs was observed in the control $(n=10), S A(n=10)$ and ACS (n=11) groups. C. GARP gene expression was compared between the treated and untreated cells from each group. D. The TGF- $\beta 1$ gene expression was compared between the treated and untreated cells from each group. E. The frequencies of Th1, Th17 and Th2 cells were measured and compared to samples that were not treated with hemin. Error bars, SD; ${ }^{* *} \mathrm{P}<0.01$ compared to the no hemin group; ns, $\mathrm{P}>0.05$ compared to the no hemin group.

Assessment of the effect of HO-1 on the expression of GARP and function of activated Tregs and on the frequency of Th1, Th17 and Th2 cells in each group

The $\mathrm{T}$ cells from all of the study subjects were treated with $10 \mathrm{ng} / \mathrm{ml}$ hemin for $48 \mathrm{~h}$ and subsequently activated by anti-CD3 and anti-CD28 antibodies. We then re-evaluated the effect of HO-1 on GARP expression and the function of the activated Tregs among the three groups. As shown in Fig. 4A, the expression of GARP on CD $4^{+} \mathrm{CD} 25^{+} \mathrm{T}$ cells was $9.83 \pm 1.28 \%$ 
Fig. 5. The effect of HO-1 on the expression of certain genes. $\mathrm{T}$ cells from control $(n=20)$, SA $(n=30)$, and ACS $(n=40)$ patients were co-cultured with $10 \mathrm{ng} / \mathrm{ml}$ of hemin for $48 \mathrm{~h}$ and then stimulated with anti-CD3 and anti-CD28 antibodies. The relative mRNA expression levels of T-bet, IFN- $\gamma$, ROR $\gamma \mathrm{t}$, IL-17, GATA3 and IL-4 were detected and compared with the cells that did not receive hemin in each group. Error bars, SD; ** $\mathrm{P}<0.01$ compared with the no hemin group; ns, $\mathrm{P}>0.05$ compared with the no hemin group.

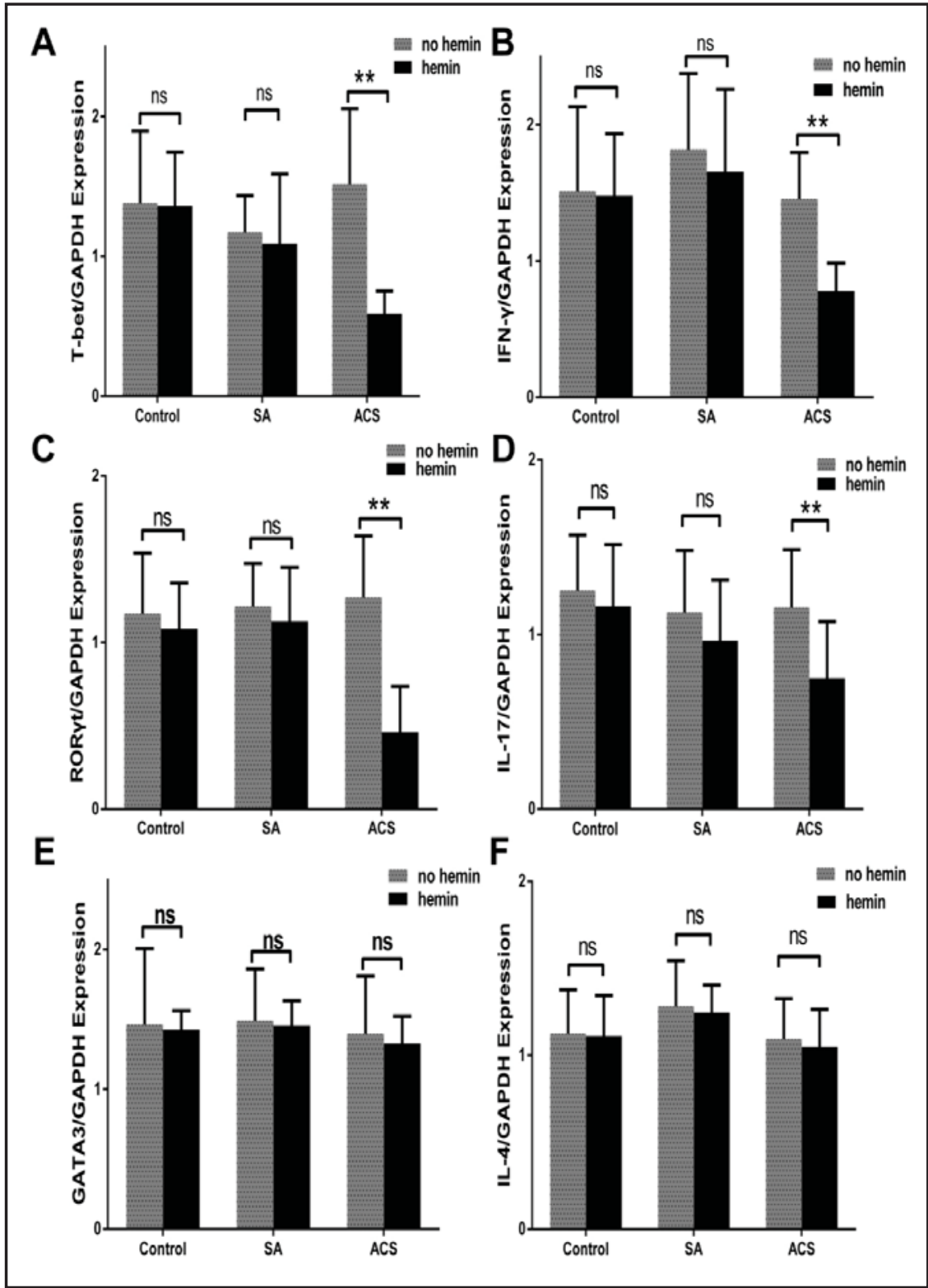

in the control group, $9.32 \pm 1.16 \%$ in the SA group, and $9.08 \pm 1.56 \%$ in the ACS group after stimulation in vitro, and no significant differences were found among the three groups $(\mathrm{P}=0.68)$. The effect of HO-1 on the suppressive properties of activated Tregs was also measured in the three groups. Although incubation with hemin increased the ability of the Tregs to suppress the proliferation of Tresps in each group, the changes in the suppressor function of Tregs from patients with ACS were more significant than those from patients with SA or the control group ( $\mathrm{P}<0.01$; Fig. 4B). In addition, $\mathrm{T}$ cells from the ACS group were more sensitive to HO- 1 in terms of GARP and TGF- $\beta 1$ mRNA induction compared with cells from the other two groups $(\mathrm{P}<0.01$; Fig. $4 \mathrm{C}$ and $\mathrm{D})$.

We then found that the frequencies of Th1 and Th17 cells were decreased to different degrees in the three groups. As shown in Fig. 4E, the frequency of Th1 and Th17 cells was significantly lower among $\mathrm{T}$ cells treated with hemin compared with untreated cells in the ACS group $(9.76 \pm 1.6 \%$ vs. $20.3 \pm 2.53 \%, \mathrm{P}<0.01 ; 1.45 \pm 0.86 \%$ vs. $3.17 \pm 1.12 \%, \mathrm{P}<0.01$, respectively). A similar decrease was not observed in the SA group $(\mathrm{P}=0.52$ and $\mathrm{P}=0.4$, respectively) or the control group ( $\mathrm{P}=0.6$ and $\mathrm{P}=0.5$, respectively). However, there were no significant differences in the frequencies of Th2 cells compared with cells left untreated in 

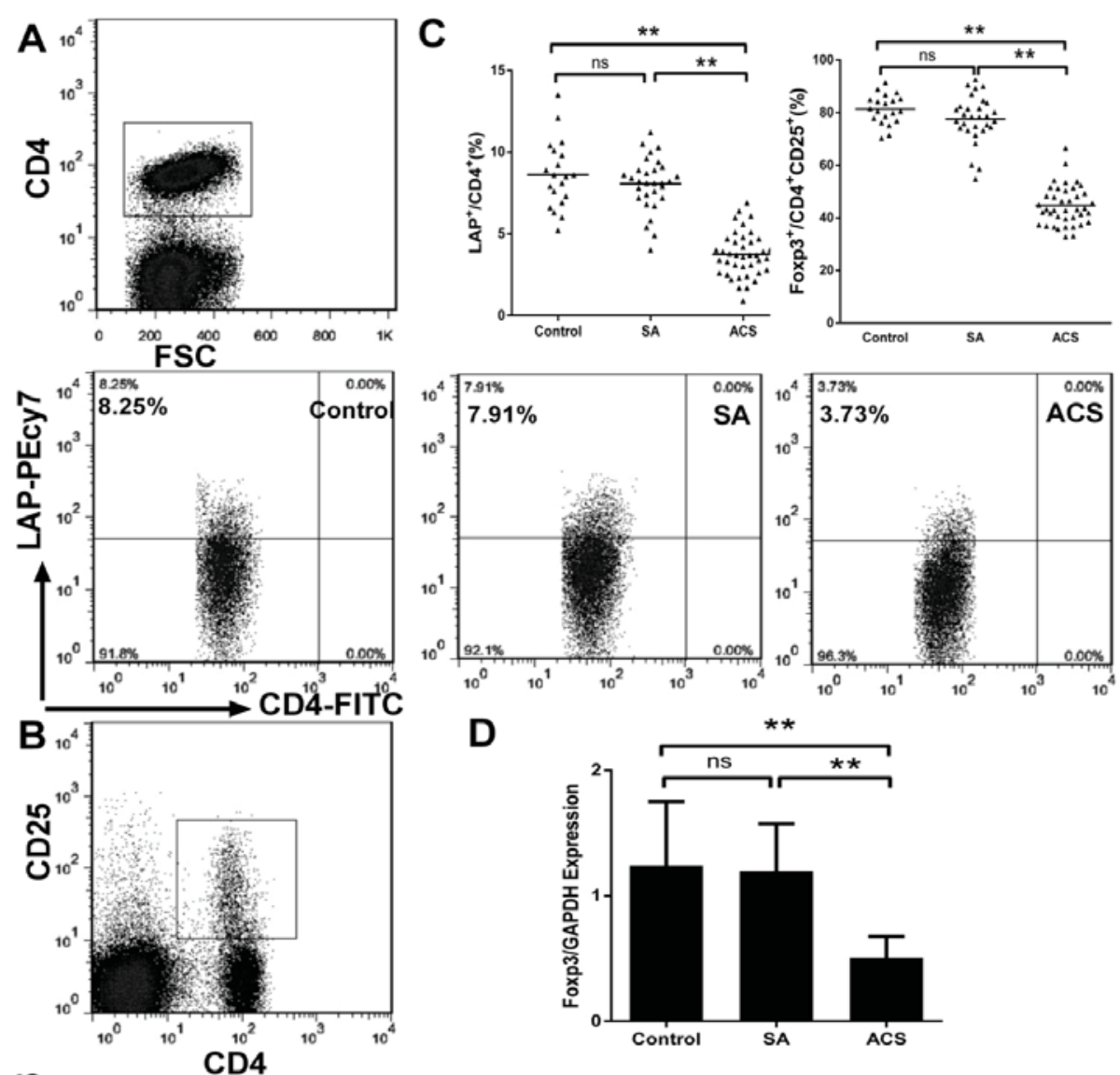

D
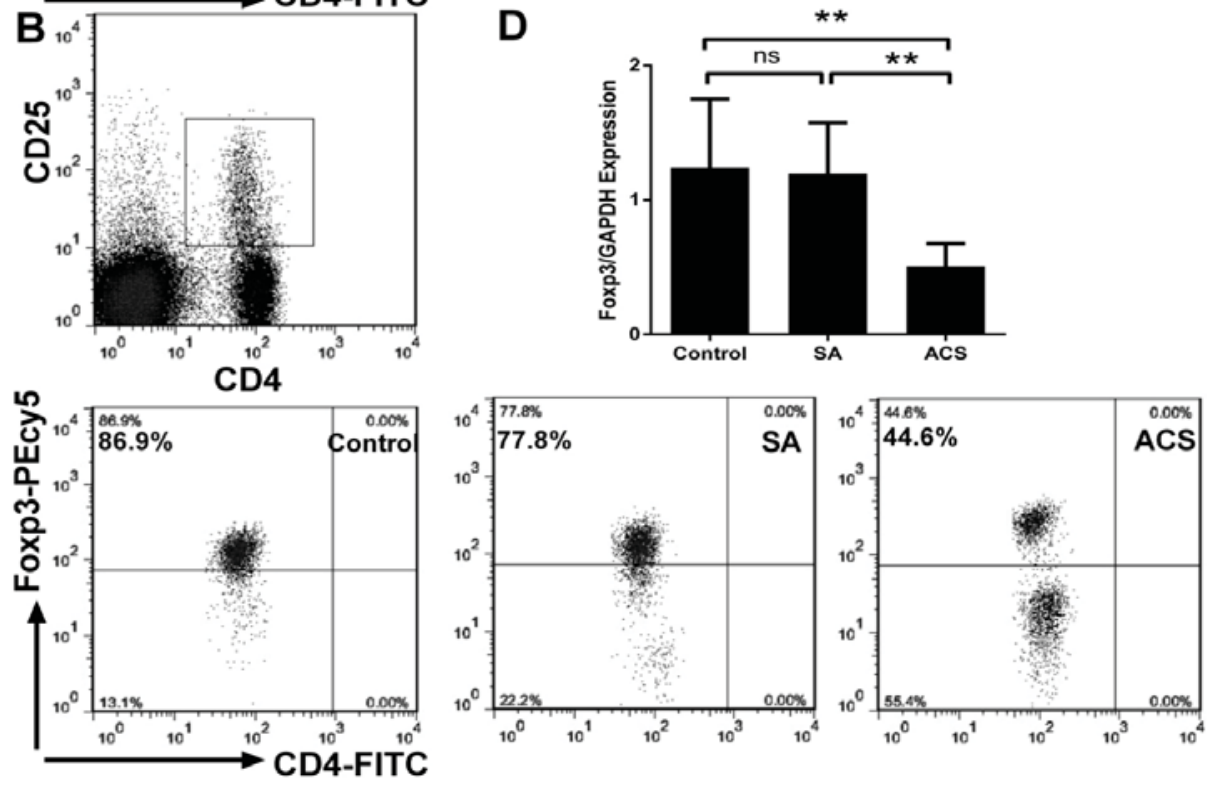

Fig. 6. Decreased expression of LAP and Foxp3 in activated T cells from patients with ACS. T cells were isolated and stimulated from control $(n=20)$, SA $(n=30)$ and ACS $(n=40)$ patients. A. CD4 ${ }^{+}$T cells were gated by the isotype control. Representative FACS images show LAP expression on stimulated CD4+ T cells. B. Representative FSC/SSC dot plot showing the gated $\mathrm{CD} 4^{+} \mathrm{CD} 25^{+} \mathrm{T}$ cells by the isotype control and representative FACS results showing Foxp3 expression in $\mathrm{CD} 4^{+} \mathrm{CD} 25^{+} \mathrm{T}$ cells from a single patient in each group after stimulation in vitro. C. Comparison of LAP and Foxp3 expression among the three groups. D. The gene expression Foxp3 was measured in each group. Error bars, SD; ${ }^{* *} \mathrm{P}<0.01$ vs. control or SA; ns, $\mathrm{P}>0.05$ vs. control.

the control group, the SA group or the ACS group $(\mathrm{P}=0.71, \mathrm{P}=0.58$, and $\mathrm{P}=0.24$, respectively; Fig. 4E).

Assessment of the effect of HO-1 on gene expression in Th1, Th17 and Th2 cells in each group

Compared with cells left untreated, the Th1-associated T-bet and IFN- $\gamma$, and Th17associated ROR $\gamma$ t and IL-17 gene expression levels were markedly lower in the ACS group than in the SA and control groups (all $\mathrm{P}<0.01$; Fig. 5A-D). However, no obvious differences 

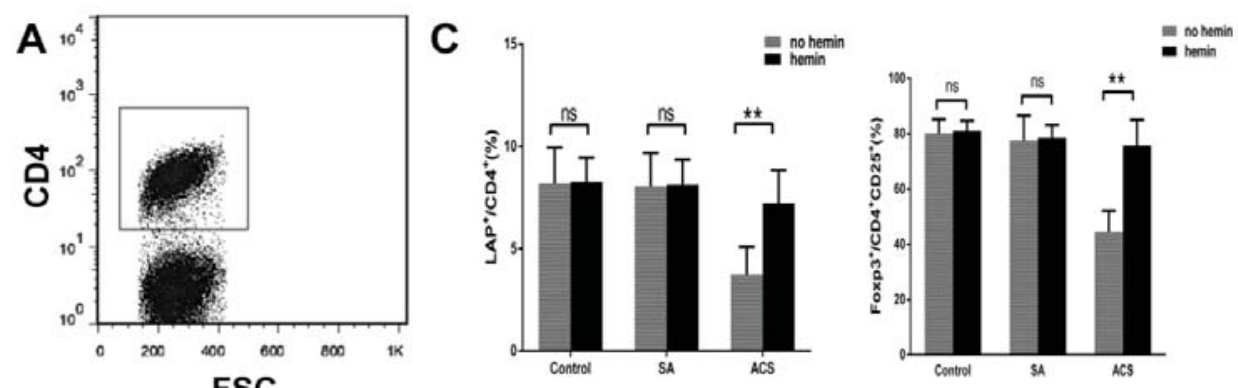

FSC
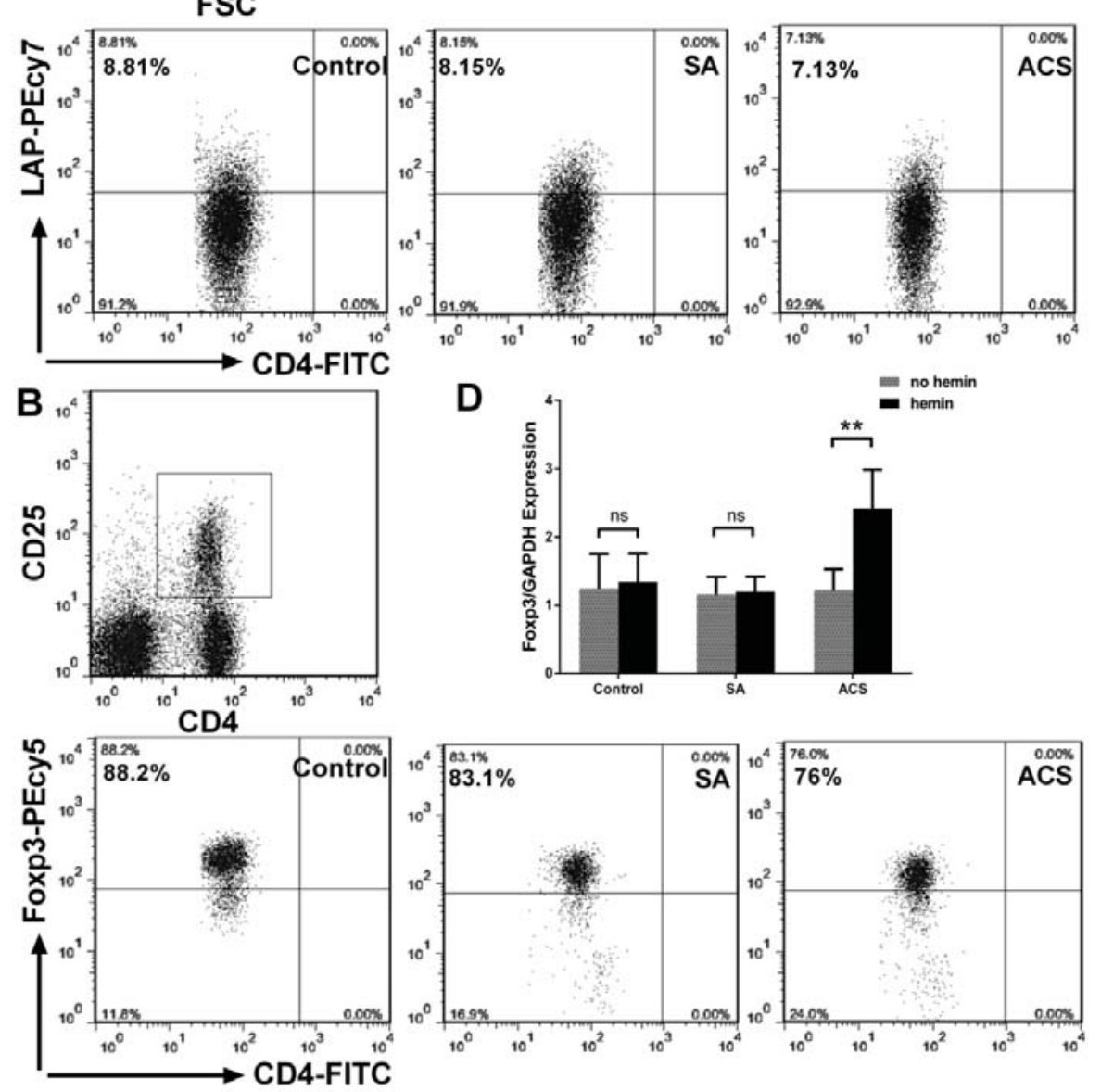

Fig. 7. HO-1 significantly promoted the expression of LAP and Foxp3 in activated T cells from patients with ACS. T cells isolated from control $(n=20), S A(n=30)$ and ACS $(n=40)$ patients were incubated with $10 \mathrm{ng} / \mathrm{ml}$ hemin for $48 \mathrm{~h}$ and subsequently stimulated with anti-CD3 and anti-CD28 antibodies. A. CD4 ${ }^{+}$T cells were gated by the isotype control. Representative FACS plots showing the LAP expression by $\mathrm{CD}^{+}{ }^{+} \mathrm{T}$ cells in each group. B. Representative FSC/SSC dot plot showing the gated CD $4^{+} \mathrm{CD} 25^{+} \mathrm{T}$ cells by the isotype control and representative FACS results showing Foxp3 expression in $\mathrm{CD} 4^{+} \mathrm{CD} 25^{+} \mathrm{T}$ cells from each group. $\mathrm{C}$. The expression of LAP and Foxp3 were analyzed and compared to samples that were not treated with hemin. D. The gene expression of Foxp3 was measured and compared to samples that were not treated with hemin. Error bars, $\mathrm{SD} ;{ }^{* *} \mathrm{P}<0.01$ compared to the no hemin group; $\mathrm{ns}, \mathrm{P}>0.05$ compared to the no hemin group.

between the treated and untreated cells were observed in the T-bet, IFN- $\gamma$, ROR $\gamma$ t and IL-17 gene expression levels between the $\mathrm{SA}(\mathrm{P}=0.31, \mathrm{P}=0.38, \mathrm{P}=0.7$, and $\mathrm{P}=0.32$, respectively) and control $(\mathrm{P}=0.47, \mathrm{P}=0.54, \mathrm{P}=0.73$, and $\mathrm{P}=0.56$, respectively) groups. In addition, no significant attenuation of Th2-related GATA3 or IL-4 gene expression was observed in the control 

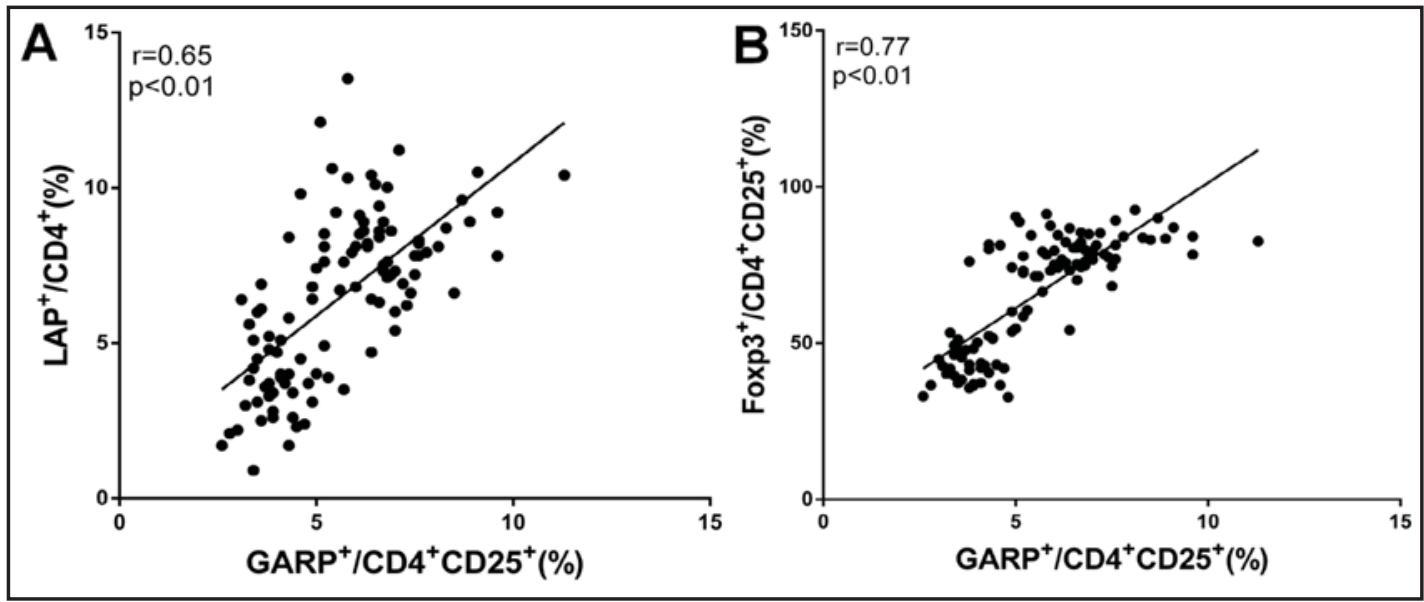

Fig. 8. $\mathrm{GARP}^{+} \mathrm{CD} 4^{+} \mathrm{CD} 25^{+}$Treg cells were closely correlated with Foxp3 expression in $\mathrm{CD} 4{ }^{+} \mathrm{CD} 25^{+} \mathrm{T}$ cells and $\mathrm{LAP}^{+} \mathrm{CD} 4^{+} \mathrm{T}$ cells. After $24 \mathrm{~h}$ of stimulation, the untreated $\mathrm{T}$ cells from control $(\mathrm{n}=20), \mathrm{SA}(\mathrm{n}=30)$ and ACS $(n=40)$ groups were used to analyze the relationships among GARP, LAP and Foxp3 expression. A. GAR$\mathrm{P}^{+} \mathrm{CD} 4{ }^{+} \mathrm{CD} 25^{+}$Treg levels positively correlated with $\mathrm{LAP}^{+} \mathrm{CD} 4^{+} \mathrm{T}$ cells $(\mathrm{r}=0.65, \mathrm{P}<0.01)$. B. GARP ${ }^{+} \mathrm{CD} 4^{+} \mathrm{CD} 25^{+} \mathrm{T}-$ reg levels positively correlated with Foxp3 expression in $\mathrm{CD} 4{ }^{+} \mathrm{CD} 25^{+} \mathrm{T}$ cells $(\mathrm{r}=0.77, \mathrm{P}<0.01)$.

( $\mathrm{P}=0.66$ and $\mathrm{P}=0.71$, respectively), $\mathrm{SA}(\mathrm{P}=0.53$ and $\mathrm{P}=0.64$, respectively), or ACS groups ( $\mathrm{P}=0.35$ and $\mathrm{P}=0.56$, respectively) (Fig. $5 \mathrm{E}$ and $\mathrm{F}$ ).

Attenuated expression of LAP and Foxp3 in stimulated T cells from the ACS group

The expression of LAP and Foxp3 in stimulated T cells from each group were detected by performing flow cytometric analysis. The expression of LAP on activated T cells and Foxp3 in activated $\mathrm{CD} 4^{+} \mathrm{CD} 25^{+} \mathrm{T}$ cells were clearly lower in the ACS group $(3.74 \pm 1.36 \%$ and, $44.65 \pm 7.42 \%$, respectively) than in patients with SA $(8.06 \pm 1.63 \%$ and $77.55 \pm 8.96 \%$, respectively) or control subjects $(8.18 \pm 1.77 \%$ and $79.32 \pm 5.61 \%$, respectively) $(\mathrm{P}<0.01$; Fig. 6 A-C). However, no significant differences were found between the SA and control groups for the expressions of LAP and Foxp3 ( $\mathrm{P}=0.61$ and $\mathrm{P}=0.76$, respectively). Similar results were observed for the expression of the Foxp3 gene ( $\mathrm{P}<0.01$; Fig. 6D).

Assessment of the effect of HO-1 on the expression of LAP and Foxp3 in activated T cells from patients with ACS

Following incubation with hemin, HO-1 promoted the expression of LAP and Foxp3 in the ACS groups (Fig. 7A-C). We found that $\mathrm{T}$ cells from the ACS group were more sensitive to HO-1 in terms of Foxp3 and LAP induction compared with cells from the other two groups $(\mathrm{P}<0.01)$ after stimulation in vitro. In comparison, no clear differences were observed in the SA and control groups for the expression of LAP ( $\mathrm{P}=0.33$ and $\mathrm{P}=0.46$, respectively) and Foxp3 $(\mathrm{P}=0.52$ and $\mathrm{P}=0.57$, respectively) compared with cells left untreated. In addition, we confirmed these results by measuring the gene expression of Foxp3 after treating the $\mathrm{T}$ cells with hemin $(\mathrm{P}<0.01$; Fig. 7D).

Spearman correlation analysis of the expression of Foxp3 and LAP with GARP

After $24 \mathrm{~h}$ of stimulation with soluble anti-human CD3 and anti-human CD28 antibodies, The untreated T cells from the control $(n=20), S A(n=30)$ and ACS $(n=40)$ groups were used to evaluate the relationships among GARP, LAP and Foxp3 expression using Spearman's correlation analysis. As shown in Fig. $8 \mathrm{~A}, \mathrm{LAP}^{+} \mathrm{CD} 4^{+} \mathrm{T}$ cells showed a positive correlation with the frequencies of GARP ${ }^{+} \mathrm{CD} 4^{+} \mathrm{CD} 25^{+} \mathrm{T}$ cells $(\mathrm{r}=0.65, \mathrm{P}<0.01)$. In addition, there was a positive correlation between the expression of GARP and Foxp3 in $\mathrm{CD}^{+} \mathrm{CD} 25^{+} \mathrm{T}$ cells $(\mathrm{r}=0.77, \mathrm{P}<0.01$; Fig. 8B). 


\section{Cellular Physiology and Biochemistry}

Cell Physiol Biochem 2015;35:553-570

\begin{tabular}{l|l}
\hline DOI: $10.1159 / 000369719$ & (C) 2015 S. Karger AG, Basel
\end{tabular}

www.karger.com/cpb

Liu et al.: HO-1 Restores GARP+Tregs from Patients with ACS

\section{Discussion}

The pathogenic immune response typically results from the excessive expansion of effector T cells and has been shown to be responsible for plaque rupture and the subsequent onset of ACS [5, 9]. Tregs are indispensable for suppressing the pathological autoreactive immune response and maintaining immune homeostasis. In some rodent models, Tregs were shown to be atheroprotective and to play a crucial role in promoting plaque stability following the induction or adoptive transfer of Tregs [28,29]. Tregs must be first activated by antigens before developing suppressive functions $[30,31]$. Therefore, promoting the function of activated Tregs may help prevent the development and destabilization of atherosclerotic plaques. GARP is identified as a biomarker specific for activated human nTregs and is not induced in non-nTregs after $\mathrm{T}$ cell receptor (TCR) [20]. GARP ${ }^{+} \mathrm{CD} 4^{+} \mathrm{CD} 25^{+}$Tregs can be used to distinguish activated Tregs. In the current study, we confirmed that the frequencies and function of $\mathrm{GARP}^{+} \mathrm{CD} 4^{+} \mathrm{CD} 25^{+}$Tregs were compromised in patients with ACS. These $\mathrm{GARP}^{+} \mathrm{CD} 4^{+} \mathrm{CD} 25^{+}$Tregs could not effectively control the excess proliferation of effector $\mathrm{T}$ cells, thus leading to a severe immune response in patients with ACS. HO-1 has been shown to interfere with the innate immune response through the regulation of innate immune cells. In the current study, we demonstrated the effects of HO-1 on adaptive immunity. In particular, HO- 1 dramatically promoted the generation of GARP ${ }^{+} \mathrm{CD} 4^{+} \mathrm{CD} 25^{+}$Tregs and enhanced their suppressive properties to decrease the pathogenic immune response in patients with ACS. These effects of HO-1 are likely achieved through the upregulated expression of GARP and LAP on activated human T cells.

Caligiuri indicated that one important reason for the pathogenic autoaggressive immune response in ACS is a flawed regulatory lymphocyte network [32]. After stimulation in vitro, we detected the number of $\mathrm{CD} 4^{+} \mathrm{CD} 25^{+} \mathrm{T}$ cells but found no significant differences in the frequencies of $\mathrm{CD} 4^{+} \mathrm{CD} 25^{+} \mathrm{T}$ cells between patients with ACS compared with patients with SA or with the control individuals. Next, we measured GARP expression on CD $4^{+} \mathrm{CD} 25^{+} \mathrm{T}$ cells and found that the expression of GARP was significantly lower in T cells isolated from ACS subjects than in SA or control subjects. In addition, our previous research had demonstrated that expression of GARP in freshly isolated $\mathrm{CD}^{+} \mathrm{T}$ cells from ACS patients significantly decreased too [14]. GARP is important for the expression of Foxp3 and for maintaining the suppressive function of activated Tregs [33]. Accordingly, our research further corroborated that the frequencies of $\mathrm{GARP}^{+} \mathrm{CD} 4^{+} \mathrm{CD} 25^{+}$Tregs and the suppressor function of activated Tregs from ACS individuals were critically impaired compared to SA or control individuals. This evidence further indicated that the attenuated number of GARP ${ }^{+} \mathrm{CD} 4^{+} \mathrm{CD} 25^{+}$Tregs was responsible for the impaired suppressive function and the destructive immune response characterized by the hyperproliferation of Th1 and Th17 cells in patients with ACS. The proinflammatory cytokines that are secreted by Th1 and Th17 destabilized the fibrous cap by promoting the activation of macrophages, inhibiting the proliferation, collagen synthesis and contractile protein expression of smooth muscle cells, and inhibiting the expression of scavenger receptor by macrophages. Together, these factors result in plaque rupture [3436]. Our study showed that there were marked increases in the frequencies of Th1 and Th17 cells and in the relative gene expression of IFN- $\gamma$ and IL-17 in patients with ACS. However, no significant differences were found between the SA and control groups. Thus, promoting GARP expression on $\mathrm{CD} 4^{+} \mathrm{CD} 25^{+} \mathrm{T}$ cells may serve as a potential therapeutic strategy for ACS.

HO-1 possesses antioxidant, antiapoptotic, and anti-inflammatory properties via the degradation of hemin, and accumulating evidence also shows that the immunoregulatory function of HO-1 is due to its regulation of the function of Tregs [37, 38]. Choi et al. demonstrated that Treg function was inhibited via the pharmacologic blockade of HO-1 [39]. In addition, Xia et al. showed that HO-1 could regulate adaptive immunity by promoting the expression of Foxp3 in CD4 $4^{+} 25^{+} \mathrm{T}$ cells and increasing the suppressor function of Tregs [27]. Our study found that the level of HO-1 mRNA was significantly lower in T cells from patients with ACS than in T cells from the SA and control groups. However, overexpression of HO-1 following hemin treatment enhanced the number of $\mathrm{GARP}{ }^{+} \mathrm{CD} 4^{+} \mathrm{CD} 25^{+}$Tregs and restored 


\section{Cellular Physiology and Biochemistry}

Cell Physiol Biochem 2015;35:553-570

\begin{tabular}{l|l}
\hline DOI: $10.1159 / 000369719$ & (C) 2015 S. Karger AG, Basel
\end{tabular}

www.karger.com/cpb

Liu et al.: HO-1 Restores GARP+Tregs from Patients with ACS

the suppressive property of activated Tregs from patients with ACS after stimulation in vitro. The increased frequencies and enhanced suppressive activity of $\mathrm{GARP}^{+} \mathrm{CD} 4^{+} \mathrm{CD} 25^{+}$Tregs could effectively inhibit the hyperproliferation of Th1 cells to maintain immune homeostasis by direct cell-cell contact and the expression of anti-inflammatory cytokine TGF- $\beta 1$. HO-1 has been shown to suppress Th17 cell-mediated immune response in some animal models $[40,41]$. Now, we further confirmed that HO- 1 inhibited the Th17-dominant response in patients with ACS. The phosphorylation of STAT3, a key signaling molecule required for Foxp3 or ROR $\gamma \mathrm{t}$ expression, plays an important role in the process of Treg and Th17 cell differentiation. Zhang et al. discovered that HO-1 increased the Treg population and decreased the Th17 population by inhibiting the protein level of p-STAT3 [40]. Hahn demonstrated that Treg/Th17 differentiation was regulated by the GARP/TGF- $\beta 1$ complex under different inflammatory conditions [42] and Wilson indicated that TGF- $\beta$ may actually suppress the differentiation of human Th17 cells [43]. We did not observe any clear effect of HO-1 on the cells from SA subjects. This may be due to the relative immune homeostasis in patients with SA. Because no significant differences were found between the SA and control groups. These results imply that HO-1 can effectively restore the impairments in Tregs from patients with ACS.

Although HO-1 enhances GARP expression and the suppressive function of activated Tregs, the mechanisms responsible for these effects remain elusive. The study by Xia et al. indicated that HO-1 induced the expression of membrane-bound TGF- $\beta 1$ as an important regulatory mechanism of augmenting Tregs cell function in an OVA-induced mouse asthmatic model [27]. TGF- $\beta$ is secreted from T cells as a latent form in which LAP is non-covalently associated with mature TGF- $\beta$ [44]. The expression of membrane-bound TGF- $\beta$ can be assessed by detecting the levels of LAP on T cells. Therefore, we detected the expression of LAP on activated CD4 ${ }^{+}$cells in each group. Although there was a much lower LAP expression in patients with ACS, the expression of LAP was surprisingly increased following treatment with hemin. This effect of hemin on LAP may be ascribed to GARP and TGF- $\beta$. Indeed, Tran et al. indicated that GARP and LAP colocalized on the surface of activated Tregs and knockdown of GARP prevented surface LAP expression on activated Tregs [20]. Oida and co-workers demonstrated that the TGF- $\beta$ induced the surface expression of LAP on murine CD4 ${ }^{+} \mathrm{T}$ cells [45]. In our study, patients with ACS showed low levels of TGF- $\beta 1, \mathrm{GARP}^{+} \mathrm{CD} 4^{+} \mathrm{CD} 25^{+}$Tregs and $\mathrm{LAP}^{+} \mathrm{CD} 4^{+} \mathrm{T}$ cells. Simultaneously, several studies have also shown that overexpression of HO- 1 could affect TGF- $\beta$ secretion [46].

Despite increased expression of LAP on activated CD4 ${ }^{+} \mathrm{T}$ cells, the non-covalent associations of TGF- $\beta$ with LAP block the interaction with its receptor; this interaction is necessary for the function of TGF- $\beta$. To become active, mature TGF- $\beta$ must be released from LAP. Stockis et al. documented that the membrane protein GARP was a receptor for LAP on the surface of activated human Tregs and showed that GARP directly interacted with LAP to release active TGF- $\beta$ [22]. Our data showed that there was a positive correlation between LAP and GARP. Similarly, Wang and colleagues confirmed that GARP regulated the bioavailability and activation of TGF- $\beta$ by binding to LAP [47]. Active TGF- $\beta$ is a pleiotropic cytokine that regulates Foxp3 expression and the function of Tregs by inducing Smad2/3 phosphorylation and subsequent binding to the Foxp3 promoter $[48,49]$. Our study found that there were lower levels of LAP and GARP on stimulated T cells from patients with ACS compared to patients with SA and the control subjects. These findings may account for the low expression of Foxp3 and the impaired suppressive function of activated Tregs from patients with ACS. In contrast, after increasing the expression of GARP and LAP with hemin treatment, we found that the expression of Foxp3 and the suppressive function of activated Tregs were enhanced. Probst-Kepper demonstrated that there was a positive feedback loop between GARP and Foxp3 and that up-regulation of Foxp3 can promote the expression of GARP in activated Tregs [33]. Our data showed that GARP is positively correlated with Foxp3 in CD4 ${ }^{+} \mathrm{CD} 25^{+} \mathrm{T}$ cells. Although we demonstrated a potential mechanism in vitro, no reliable atherosclerosis models are available to confirm these findings in vivo. Therefore, a transgenic mouse model is required to further study this hypothesis. 


\section{Cellular Physiology and Biochemistry}

Cell Physiol Biochem 2015;35:553-570

\begin{tabular}{l|l}
\hline DOI: $10.1159 / 000369719$ & (C) 2015 S. Karger AG, Basel
\end{tabular}

Publisned online: January 27, $2015 \quad$ www.karger.com/cpb

Liu et al.: HO-1 Restores GARP+Tregs from Patients with ACS

In conclusion, we further demonstrate that the reduced GARP expression and suppressive function of activated Tregs result in a mixed Th1/Th17-dominant T cell response in patients with ACS. In addition, our study is the first to illustrate that the immunoregulatory effect of HO- 1 in ACS individuals is mediated by the upregulation of LAP and GARP expression on activated T cells. These findings will help us to more effectively explore therapies for ACS.

\section{Acknowledgments}

This work was supported by grants from the National Nature Science Foundation of China (NO: 81270354 and NO: 81300213).

\section{References}

1 Hansson GK, Libby P, Schonbeck U, Yan ZQ: Innate and adaptive immunity in the pathogenesis of atherosclerosis. Circ Res 2002;91:281-291.

2 Hansson GK: Inflammation, atherosclerosis, and coronary artery disease. N Engl J Med 2005;352:16851695.

-3 Falk E, Shah PK, Fuster V: Coronary plaque disruption. Circulation 1995;92:657-671.

4 Hosono M, de Boer OJ, van der Wal AC, van der Loos CM, Teeling P, Piek JJ, Ueda M, Becker AE: Increased expression of T cell activation markers (CD25, CD26, CD40L and CD69) in atherectomy specimens of patients with unstable angina and acute myocardial infarction. Atherosclerosis 2003;168:73-80.

-5 De Palma R, Del GF, Abbate G, Chiariello M, Calabro R, Forte L, Cimmino G, Papa MF, Russo MG, Ambrosio G, Giombolini C, Tritto I, Notaristefano S, Berrino L, Rossi F, Golino P: Patients with acute coronary syndrome show oligoclonal T-cell recruitment within unstable plaque: Evidence for a local, intracoronary immunologic mechanism. Circulation 2006;113:640-646.

6 Stemme S, Rymo L, Hansson GK: Polyclonal origin of T lymphocytes in human atherosclerotic plaques. Lab Invest 1991;65:654-660.

7 Zalai CV, Kolodziejczyk MD, Pilarski L, Christov A, Nation PN, Lundstrom-Hobman M, Tymchak W, Dzavik V, Humen DP, Kostuk WJ, Jablonsky G, Pflugfelder PW, Brown JE, Lucas A: Increased circulating monocyte activation in patients with unstable coronary syndromes. J Am Coll Cardiol 2001;38:1340-1347.

-8 Daugherty A, Rateri DL: T lymphocytes in atherosclerosis: The yin-yang of Th1 and Th2 influence on lesion formation. Circ Res 2002;90:1039-1040.

-9 Methe H, Brunner S, Wiegand D, Nabauer M, Koglin J, Edelman ER: Enhanced T-helper-1 lymphocyte activation patterns in acute coronary syndromes. J Am Coll Cardiol 2005;45:1939-1945.

-10 Szodoray P, Timar O, Veres K, Der H, Szomjak E, Lakos G, Aleksza M, Nakken B, Szegedi G, Soltesz P: TH1/ TH2 imbalance, measured by circulating and intracytoplasmic inflammatory cytokines--immunological alterations in acute coronary syndrome and stable coronary artery disease. Scand J Immunol 2006;64:336344.

11 Frostegard J, Ulfgren AK, Nyberg P, Hedin U, Swedenborg J, Andersson U, Hansson GK: Cytokine expression in advanced human atherosclerotic plaques: Dominance of pro-inflammatory (Th1) and macrophagestimulating cytokines. Atherosclerosis 1999;145:33-43.

12 Hashmi S, Zeng QT: Role of interleukin-17 and interleukin-17-induced cytokines interleukin-6 and interleukin-8 in unstable coronary artery disease. Coron Artery Dis 2006;17:699-706.

13 Takatori H, Kanno Y, Watford WT, Tato CM, Weiss G, Ivanov II, Littman DR, O'Shea JJ: Lymphoid tissue inducer-like cells are an innate source of IL-17 and IL-22. J Exp Med 2009;206:35-41.

14 Meng K, Zhang W, Zhong Y, Mao X, Lin Y, Huang Y, Lang M, Peng Y, Zhu Z, Liu Y, Zhao X, Yu K, Wu B, Ji Q, Zeng Q: Impairment of circulating CD4CD25(+)GARP(+) regulatory t cells in patients with acute coronary syndrome. Cell Physiol Biochem 2014;33:621-632.

15 Mor A, Luboshits G, Planer D, Keren G, George J: Altered status of CD4(+)CD25(+) regulatory T cells in patients with acute coronary syndromes. Eur Heart J 2006;27:2530-2537.

16 Fontenot JD, Gavin MA, Rudensky AY: Foxp3 programs the development and function of CD4+CD25+ regulatory T cells. Nat Immunol 2003;4:330-336. 


\section{Cellular Physiology and Biochemistry}

Cell Physiol Biochem 2015;35:553-570

\begin{tabular}{l|l}
\hline DOI: $10.1159 / 000369719$ & (C) 2015 S. Karger AG, Basel
\end{tabular}

Liu et al.: HO-1 Restores GARP+Tregs from Patients with ACS

-17 Brunkow ME, Jeffery EW, Hjerrild KA, Paeper B, Clark LB, Yasayko SA, Wilkinson JE, Galas D, Ziegler SF, Ramsdell F: Disruption of a new forkhead/winged-helix protein, scurfin, results in the fatal lymphoproliferative disorder of the scurfy mouse. Nat Genet 2001;27:68-73.

-18 Bennett CL, Christie J, Ramsdell F, Brunkow ME, Ferguson PJ, Whitesell L, Kelly TE, Saulsbury FT, Chance $\mathrm{PF}$, Ochs HD: The immune dysregulation, polyendocrinopathy, enteropathy, X-linked syndrome (IPEX) is caused by mutations of FOXP3. Nat Genet 2001;27:20-21.

-19 Roncarolo MG, Gregori S: Is FOXP3 a bona fide marker for human regulatory T cells? Eur J Immunol 2008;38:925-927.

20 Tran DQ, Andersson J, Wang R, Ramsey H, Unutmaz D, Shevach EM: GARP (LRRC32) is essential for the surface expression of latent TGF-beta on platelets and activated FOXP3+ regulatory T cells. Proc Natl Acad Sci U S A 2009;106:13445-13450.

-21 Chan DV, Somani AK, Young AB, Massari JV, Ohtola J, Sugiyama H, Garaczi E, Babineau D, Cooper KD, McCormick TS: Signal peptide cleavage is essential for surface expression of a regulatory T cell surface protein, leucine rich repeat containing 32 (LRRC32). BMC Biochem 2011;12:27.

-22 Stockis J, Colau D, Coulie PG, Lucas S: Membrane protein GARP is a receptor for latent TGF-beta on the surface of activated human Treg. Eur J Immunol 2009;39:3315-3322.

23 Araujo JA, Zhang M, Yin F: Heme oxygenase-1, oxidation, inflammation, and atherosclerosis. Front Pharmacol 2012;3:119.

24 Liu Y, Li P, Lu J, Xiong W, Oger J, Tetzlaff W, Cynader M: Bilirubin possesses powerful immunomodulatory activity and suppresses experimental autoimmune encephalomyelitis. J Immunol 2008;181:1887-1897.

-25 Pae HO, Oh GS, Choi BM, Chae SC, Kim YM, Chung KR, Chung HT: Carbon monoxide produced by heme oxygenase-1 suppresses T cell proliferation via inhibition of IL-2 production. J Immunol 2004;172:47444751.

26 McDaid J, Yamashita K, Chora A, Ollinger R, Strom TB, Li XC, Bach FH, Soares MP: Heme oxygenase-1 modulates the allo-immune response by promoting activation-induced cell death of $\mathrm{T}$ cells. Faseb J 2005;19:458-460.

-27 Xia ZW, Zhong WW, Xu LQ, Sun JL, Shen QX, Wang JG, Shao J, Li YZ, Yu SC: Heme oxygenase-1-mediated CD4+CD25high regulatory T cells suppress allergic airway inflammation. J Immunol 2006;177:5936-5945.

28 Mor A, Planer D, Luboshits G, Afek A, Metzger S, Chajek-Shaul T, Keren G, George J: Role of naturally occurring CD4+ CD25+ regulatory T cells in experimental atherosclerosis. Arterioscler Thromb Vasc Biol 2007;27:893-900.

29 Sasaki N, Yamashita T, Takeda M, Shinohara M, Nakajima K, Tawa H, Usui T, Hirata K: Oral anti-CD3 antibody treatment induces regulatory $\mathrm{T}$ cells and inhibits the development of atherosclerosis in mice. Circulation 2009;120:1996-2005.

-30 Takahashi T, Kuniyasu Y, Toda M, Sakaguchi N, Itoh M, Iwata M, Shimizu J, Sakaguchi S: Immunologic selftolerance maintained by CD25+CD4+ naturally anergic and suppressive T cells: Induction of autoimmune disease by breaking their anergic/suppressive state. Int Immunol 1998;10:1969-1980.

-31 Thornton AM, Shevach EM: CD4+CD25+ immunoregulatory T cells suppress polyclonal T cell activation in vitro by inhibiting interleukin 2 production. J Exp Med 1998;188:287-296.

-32 Caligiuri G, Nicoletti A: Lymphocyte responses in acute coronary syndromes: Lack of regulation spawns deviant behaviour. Eur Heart J 2006;27:2485-2486.

-33 Probst-Kepper M, Geffers R, Kroger A, Viegas N, Erck C, Hecht HJ, Lunsdorf H, Roubin R, MoharreghKhiabani D, Wagner K, Ocklenburg F, Jeron A, Garritsen H, Arstila TP, Kekalainen E, Balling R, Hauser H, Buer J, Weiss S: GARP: A key receptor controlling FOXP3 in human regulatory T cells. J Cell Mol Med 2009;13:3343-3357.

- 34 Hansson GK, Hellstrand M, Rymo L, Rubbia L, Gabbiani G: Interferon gamma inhibits both proliferation and expression of differentiation-specific alpha-smooth muscle actin in arterial smooth muscle cells. J Exp Med 1989;170:1595-1608.

-35 Amento EP, Ehsani N, Palmer H, Libby P: Cytokines and growth factors positively and negatively regulate interstitial collagen gene expression in human vascular smooth muscle cells. Arterioscler Thromb 1991;11:1223-1230.

-36 Geng YJ, Hansson GK: Interferon-gamma inhibits scavenger receptor expression and foam cell formation in human monocyte-derived macrophages. J Clin Invest 1992;89:1322-1330. 


\section{Cellular Physiology and Biochemistry}

Cell Physiol Biochem 2015;35:553-570

\begin{tabular}{l|l}
\hline DOI: $10.1159 / 000369719$ & (c) 2015 S. Karger AG, Basel
\end{tabular}

Liu et al.: HO-1 Restores GARP+Tregs from Patients with ACS

-37 Soares MP, Marguti I, Cunha A, Larsen R: Immunoregulatory effects of HO-1: How does it work? Curr Opin Pharmacol 2009;9:482-489.

- 38 Brusko TM, Wasserfall CH, Agarwal A, Kapturczak MH, Atkinson MA: An integral role for heme oxygenase-1 and carbon monoxide in maintaining peripheral tolerance by CD4+CD25+ regulatory T cells. J Immunol 2005;174:5181-5186.

-39 Choi BM, Pae HO, Jeong YR, Kim YM, Chung HT: Critical role of heme oxygenase-1 in Foxp3-mediated immune suppression. Biochem Biophys Res Commun 2005;327:1066-1071.

-40 Zhang Y, Zhang L, Wu J, Di C, Xia Z: Heme oxygenase-1 exerts a protective role in ovalbumin-induced neutrophilic airway inflammation by inhibiting Th17 cell-mediated immune response. J Biol Chem 2013;288:34612-34626.

-41 Gobert AP, Verriere T, Asim M, Barry DP, Piazuelo MB, de Sablet T, Delgado AG, Bravo LE, Correa P, Peek RJ, Chaturvedi R, Wilson KT: Heme oxygenase-1 dysregulates macrophage polarization and the immune response to helicobacter pylori. J Immunol 2014;193:3013-3022.

-42 Hahn SA, Stahl HF, Becker C, Correll A, Schneider FJ, Tuettenberg A, Jonuleit H: Soluble GARP has potent antiinflammatory and immunomodulatory impact on human CD4(+) T cells. Blood 2013;122:1182-1191.

43 Wilson NJ, Boniface K, Chan JR, McKenzie BS, Blumenschein WM, Mattson JD, Basham B, Smith K, Chen T, Morel F, Lecron JC, Kastelein RA, Cua DJ, McClanahan TK, Bowman EP, de Waal MR: Development, cytokine profile and function of human interleukin 17-producing helper T cells. Nat Immunol 2007;8:950-957.

-44 Tran DQ: TGF-beta: The sword, the wand, and the shield of FOXP3(+) regulatory T cells. J Mol Cell Biol 2012;4:29-37.

45 Oida T, Weiner HL: TGF-beta induces surface LAP expression on murine CD4 T cells independent of Foxp3 induction. PLoS One 2010;5:e15523.

46 Jiang YB, Zhang XL, Tang YL, Ma GS, Shen CX, Wei Q, Zhu Q, Yao YY, Liu NF: Effects of heme oxygenase-1 gene modulated mesenchymal stem cells on vasculogenesis in ischemic swine hearts. Chin Med J (Engl) 2011;124:401-407.

47 Wang R, Zhu J, Dong X, Shi M, Lu C, Springer TA: GARP regulates the bioavailability and activation of TGFbeta. Mol Biol Cell 2012;23:1129-1139.

-48 Fantini MC, Becker C, Monteleone G, Pallone F, Galle PR, Neurath MF: Cutting edge: TGF-beta induces a regulatory phenotype in CD4+CD25- T cells through Foxp3 induction and down-regulation of Smad7. J Immunol 2004;172:5149-5153.

49 Tone Y, Furuuchi K, Kojima Y, Tykocinski ML, Greene MI, Tone M: Smad3 and NFAT cooperate to induce Foxp3 expression through its enhancer. Nat Immunol 2008;9:194-202. 